\title{
33. MIOCENE SHALLOW-WATER CARBONATES ON THE ERATOSTHENES SEAMOUNT, EASTERNMOST MEDITERRANEAN SEA ${ }^{1}$
}

\author{
Alastair H.F. Robertson ${ }^{2}$
}

\begin{abstract}
Miocene shallow-water limestones of the Eratosthenes Seamount add considerably to the picture of widespread and heterogeneous Mediterranean Miocene reef development. Shallow-water limestones were cored at two sites on the Eratosthenes Seamount during Ocean Drilling Program Leg 160, one on the plateau area and one on the upper northern slopes. The limestones at Site 966 are dated as Miocene by use of benthic foraminifers, whereas those at Site 965, although lacking diagnostic fossils, are inferred to be of late Miocene age from the evidence of preliminary strontium isotopic dating. At Site 966, shallow-water limestones are underlain by upper Eocene bathyal pelagic carbonates and overlain by a mass-flow unit of early Pliocene age; by contrast, at Site 965, paleosols, of assumed Messinian age, overlie the Miocene limestones. The limestones at both sites are mainly composed of calcareous red algae (often as rhodoliths), coral (e.g., Porites), large benthic foraminifers, bivalves, echinoderm plates, and minor sponge spicules. The frame-building material is mainly reworked by gravity (where locally coarse) and by ocean currents (where finer grained). Sediment at Site 965 is relatively coarse, which suggests a proximal reef setting. Planktonic foraminifers are common, indicating proximity to an open-marine setting. By contrast, bioclastic material at Site 966 is mainly relatively fine grained and accumulated in a lagoonal setting, characterized by lime-mud, with some in situ microbialmat development.

Carbonates at both sites underwent a similar diagenetic history. Early void-filling cement included fibrous, acicular cement, of marine origin. Minor aragonite is preserved locally, but primary carbonate is recrystallized to low-magnesian calcite. The development of extensive dissolution porosity and calcite cement are attributed to flushing by meteoric waters during the Messinian, a period of emergence of the Eratosthenes Seamount. Common dolomite possibly formed in a mixing zone-related setting associated with marine transgression in the early Pliocene. Minor opal and microcrystalline chert may owe its origin to dissolution of sponge spicules that are still locally preserved.

Comparisons with other Miocene Mediterranean reef limestones indicate many similarities with lower Miocene reefs in southeastern Cyprus; the latter developed as scattered patch reefs on a flat, relatively tectonically stable area. There are also marked similarities with the upper Miocene reefs of the Pelagian Block in the Central Mediterranean that were isolated from terrigenous input by surrounding deep-water basins. Alternatively, the lower Miocene Eratosthenes reefs possibly formed an atoll-like structure, with coral-calcareous algal growths around the periphery, and lime mud accumulation within an internal lagoon, similar to many modern atolls. Shallow-water carbonate deposition was initiated after the Paleogene, following about 1 $\mathrm{km}$ of tectonic uplift, and was terminated by the late Miocene salinity crisis.
\end{abstract}

\section{INTRODUCTION}

Shallow-water limestones of Miocene age were recovered during drilling of Leg 160 from two sites on the Eratosthenes Seamount in the Eastern Mediterranean Sea, one on the seamount plateau area (Site 966), and one on the upper part of the northern slopes of the seamount (Site 965). This discovery opens up a new perspective on Miocene reefs in the Mediterranean. The objective of this paper is to discuss the sedimentology, diagenesis, and origin of the shallow-water carbonates in relation to the regional geological setting, especially Cyprus, where similar Miocene carbonates have developed.

\section{REGIONAL GEOLOGICAL SETTING AND AGE}

During the Miocene, the Eratosthenes Seamount formed a shallow-water carbonate build up in the easternmost Mediterranean Sea located about $50 \mathrm{~km}$ south of Cyprus (Emeis, Robertson, Richter, et al., 1996; Fig. 1). During the middle to late Eocene and Late Creta-

'Robertson, A.H.F., Emeis, K.-C., Richter, C., and Camerlenghi, A. (Eds.), 1998. Proc. ODP, Sci. Results, 160: College Station, TX (Ocean Drilling Program).

${ }^{2}$ University of Edinburgh, Department of Geology and Geophysics, West Mains Road, Edinburgh, EH9 3JW, United Kingdom. Alastair.Robertson@ed.ac.uk ceous, the seamount was located in deep water (i.e., at bathyal depths of more than $1000 \mathrm{~m}$ ) undergoing pelagic carbonate accumulation (Robertson et al., Chap. 32, this volume). After deposition of the Eocene succession that was cored at Site 966 the seamount was tectonically uplifted. This event was possibly related to northward subduction along the Cyprus active margin. During the Pliocene and Pleistocene, the seamount then subsided, so that the present water depths do not reflect the bathymetry in the Miocene.

Biostratigraphic age determination has proved to be problematic in view of the altered nature and absence of many age diagnostic fossils. The shallow-water limestones at Site 966, presently located on the crestal area of the seamount, are dated only as Miocene, as indicated by sparse occurrences of large foraminifers (Emeis, Robertson, Richter, et al., 1996; I. Premoli-Silva, pers. comm., 1996). Shallowwater limestones at Site 965, now located on the upper northern slopes of the seamount, lack diagnostic fossils, but are inferred to be of late Miocene age on the basis of two preliminary strontium isotopic age dates (E. Frankel and A. Newton, pers. comm., 1996).

At the end of the Miocene, the Eratosthenes Seamount in the area of Sites 965 and 966 was subaerially exposed, which allowed the development of paleosols at Site 965 (Emeis, Robertson, Richter, et al., 1996). Evidence particularly from Site 966 shows that the seamount subsided in the early Pliocene. The initial stages of this subsidence were accompanied by the deposition of distinctive matrix-supported breccias, including clasts of shallow-water carbonate similar to the

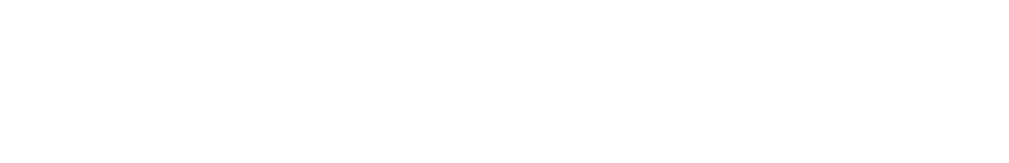




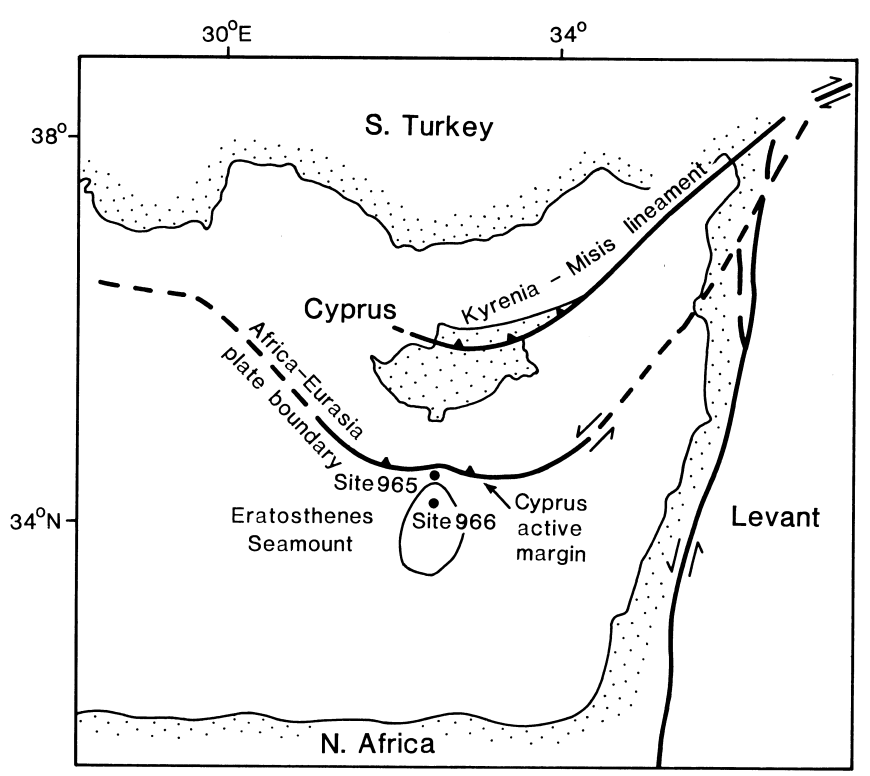

Figure 1. Outline tectonic map of the Eastern Mediterranean showing the setting of the Eratosthenes Seamount in relation to the Africa-Eurasia plate boundary (i.e., the Cyprus active margin).

underlying Miocene limestone (Robertson, Chap. 37, this volume). Collapse and subsidence of Eratosthenes are inferred to relate to arrival and partial consumption of the seamount at the Cyprus trench (Fig. 2).

\section{LITHOSTRATIGRAPHY}

In general, the successions recovered from both Sites 965 and 966 (i.e., Holes 965A and 966F) are similar. Some general features that establish this similarity are as follows. The successions at both sites are dominated by alternations of wackestone and packstones-grainstones, on scales from $<10 \mathrm{~cm}$ to many meters (Figs. 3, 4A, 4B). Gradations are relatively sharp, over several centimeters, and are identified by differences in cementation (e.g., throughout Core 160-965A$12 \mathrm{X})$. Intraclasts in the packstones-grainstones are commonly composed of wackestone. Minor lithologies include greenish packstonegrainstone, with common benthic foraminifers (e.g., throughout Core 160-966F-8R). Rare intervals include bivalve shells and calcareous algal fragments, both up to $5 \mathrm{~cm}$ in size (e.g., throughout Core 160$966 \mathrm{~F}-7 \mathrm{R})$. Bioclasts in such layers are typically more rounded than in the adjacent finer grained horizons (e.g., throughout Core 160-966F10R).

Sedimentary structures at both sites include common evidence of reworking by currents in the form of parallel lamination and microcross-lamination. Reworked limestones contain variable admixtures of densely packed fragments of shells, coral, and calcareous algae, together with benthic foraminifers (e.g., throughout Cores 160-966F$7 \mathrm{R}$ and $11 \mathrm{R}$ ) and intraclasts. Minor burrowing is also observed locally. The successions at the two sites are described individually in more detail in the following section.

\section{Hole 965A}

Shipboard observations showed that the lower part of the succession recovered is dominated by lime grainstones and packstones, rich in bivalves, coral fragments, oncolites, and intraclasts. The formation microscanner (FMS) data indicate the presence of very coarse material from 198 to $205 \mathrm{~m}$ below seafloor (mbsf) that corresponds to the presence of coarse coral and calcareous algal material in the cores

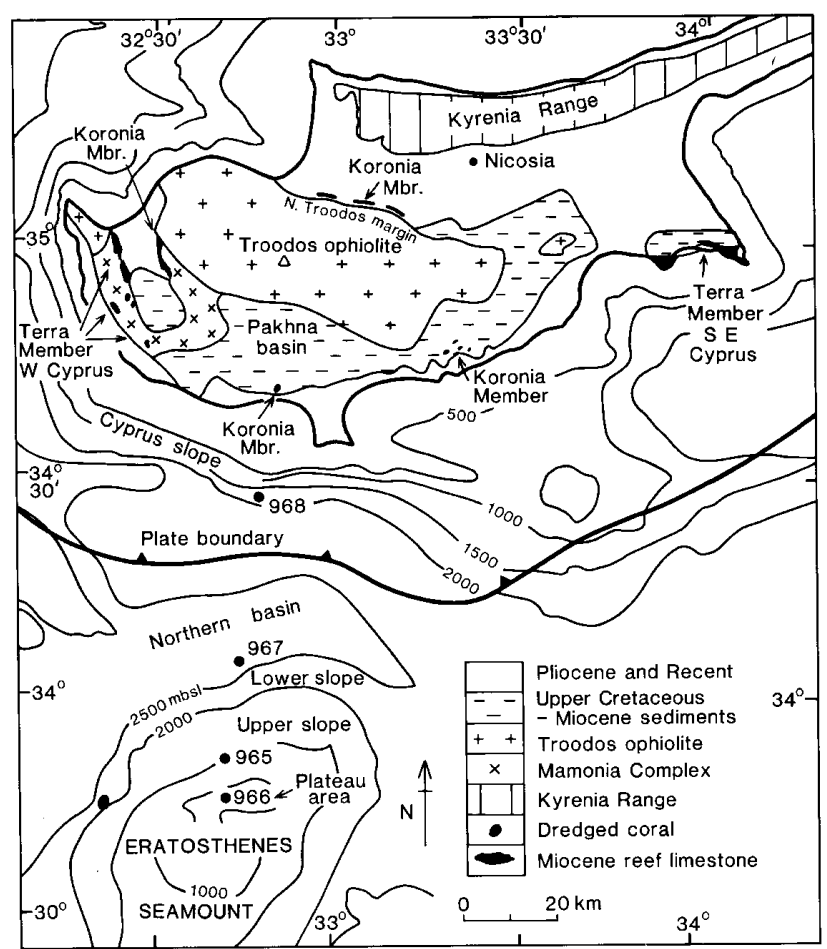

Figure 2. Map showing the setting of the Eratosthenes Seamount in relation to Miocene reef occurrences in Cyprus. These reef occurrences are the lower Miocene Terra Member and the upper Miocene Koronia Member, both of the Miocene Pakhna Formation.

(Major et al., Chap. 38, this volume). There is local evidence of early seafloor lithification and formation of hardgrounds (Fig. 5B). The recovery in the middle part of the succession includes a high proportion of wackestone and fine packstone-grainstone, whereas the higher levels are mainly packstones and grainstones, rich in bivalves, benthic foraminifers, coral, and calcareous algal fragments.

Shorebased petrographic study further revealed that the lower part of the succession at Site 965 (Cores 160-965A-23X through 27X) is dominated by partly neomorphosed wackestone, with calcareous algae, bivalve shells, polyzoans, echinoderm plates and spines, benthic foraminifers, and coral. The grains, mainly bioclasts, are relatively well sorted in some layers (e.g., interval 160-955A-22X, 0-5 cm). Local occurrences of laminated packstone are dominated by benthic foraminifers, or exhibit peloidal textures (e.g., intervals 160-965A16X, 12-14 cm, 160-965A-9X-1, 56-60 cm, 160-965A-6X -CC, 22$27 \mathrm{~cm}$, and 160-965A-5X-1, 0-4 cm). There are also rare examples of original packstone with a calcite spar. However, most grains are poorly sorted, with mainly angular, broken carbonate grains set in a variably recrystallized micritic matrix. Several intervals exhibit centimeter-scale intercalations of relatively coarse bioclastic sediment and lime mudstone that includes small planktonic foraminifers, thinwalled shell fragments, echinoderm plates, and scattered benthic foraminifers. Also, terrigenous material is present as scattered, small, angular quartz grains (e.g., in interval 160-965A-15X-1, 40-45 cm).

\section{Hole 966F}

The contact with the underlying upper Eocene, bathyal pelagic carbonate was not recovered ( $10 \mathrm{~m}$ is missing), but this is inferred to be an unconformity associated with glauconite, on the basis of evidence derived from the FMS (Major et al., Chap. 38, this volume; Flecker et al., Chap. 40, this volume). 


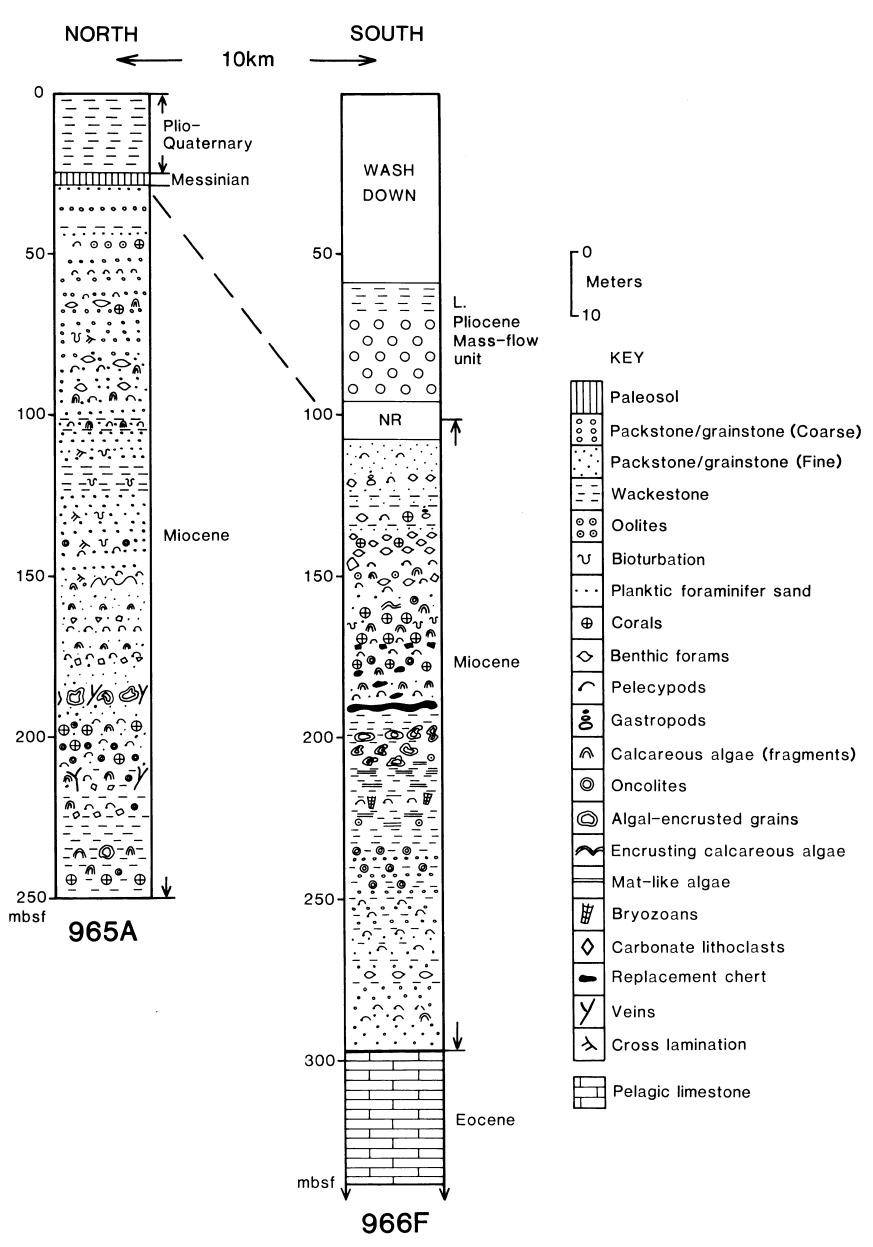

Figure 3. Sedimentary logs of Miocene successions cored at Holes 965A and 966F on the Eratosthenes Seamount. Recovery was limited, thus the logs are generalized.

Shipboard observations showed that the Miocene succession comprises about $200 \mathrm{~m}$ of shallow-water carbonates. The recovery was very limited, which allowed only a generalized sedimentary log to be constructed (Fig. 3). However, the overall succession is marked by an increase, then decrease, in the relative abundance of coralline and calcareous algal material. The succession begins with alternations of packstones and wackestones, with variable abundance of bivalve shells, algal carbonate fragments, benthic foraminifers and oncolites. Above is an interval rich in bivalves, corals, calcareous algal fragments, and calcareous intraclasts. FMS data suggest that several intervals (e.g., from 148 to $150 \mathrm{mbsf}$ ) are very coarse (Major et al., Chap. 38 , this volume), and this corresponds to part of the succession from which abundant large (i.e., greater than several centimeters) lithoclasts of corals and calcareous algae were recovered (Fig. 3). The FMS data also reveal alternations of planar and oblique features that may be interpreted as horizontal bedding and cross bedding (M.J. Jurado, pers. comm. 1997). The Miocene succession ends with alternating wackestone and fine packstone-grainstone, with numerous benthic foraminifers and shell fragments. The contact (at $\sim 114 \mathrm{mbsf}$ ) with the overlying mass-flow unit of early Pliocene age is sharp, again from FMS evidence (Emeis, Robertson, Richter, et al., 1996).

Additional information was provided by shorebased petrographic work. A sample from the lowest core recovered exhibits a packstone fabric with abundant fragments of calcareous algae, peloids, benthic foraminifers, and numerous echinoderm plates (interval 160-966F-
19R-2, 35-39 cm). A sample from near the top of the limestone succession is a packstone, rich in benthic foraminifers, mainly miliolids (interval 160-966-8R-1, 8-12 cm). Additional samples from this part of the succession (intervals 160-966F-8R-1, 4-8 cm, and 160-966F7R-1, 10-13 cm) are densely packed, imbricated shell fragments. Shells, calcareous algae and coral are mainly angular fragments, in a lime mudstone or fine packstone-grainstone matrix (e.g., interval $160-966 \mathrm{~F}-1 \mathrm{R}-4,95-100 \mathrm{~cm}$ ). Planktonic foraminifers are commonly present in the micritic matrix.

Several samples of micrite and fine packstone-grainstone contain numerous grains of quartz silt, along with minor feldspar and muscovite (e.g., interval 160-966F-8R-1, 8-12 cm). The quartz grains range from angular to subangular to rarely subrounded; most grains are clear, whereas a few are strained, or contain small inclusions or vacuoles. Some quartz grains are highly elongate.

The proportion of relatively coarse coral and calcareous algal material is less than that from Hole 965A. A coral- and calcareous algalrich unit is present in the successions of both Hole $965 \mathrm{~A}$ and $966 \mathrm{~F}$ at about 200 mbsf, although this fact may be without stratigraphic significance. In general, the sediment is less neomorphosed at Site 966, allowing more detailed studies of the primary and diagenetic textures than at Site 965. In view of the general similarities the limestones from the two holes are treated together in the following descriptions.

\section{COMPOSITION}

The following main components are present in both Holes 965A and $966 \mathrm{~F}$.

\section{Calcareous Algae}

Calcareous algae comprise fragments of mainly Lithophyllum and Mesophyllum up to several centimeters in size, admixed with other allochems (e.g., Sections 160-966F-14R-1, and 965A-5X-1; Figs. $4 \mathrm{E}, 6 \mathrm{~A}, 6 \mathrm{~B})$. Some fragments of hermatypic coral, bivalve, and both calcareous (e.g., Section 160-966F-19R-3) and carbonate intraclasts are encrusted with calcareous algae (i.e., forming red algal rhodoliths, as throughout Cores 160-966F-17X, 24X, and 25X) within a muddy, micritic sediment. Calcareous algae also form local horizontal sheetlike layers (e.g., throughout Core 160-965A-23X). In addition, bioclasts (i.e., microbial balls), up to $5 \mathrm{~cm}$ in size, are present locally (e.g., throughout Section 160-966F-19R-3). Oolites are rarely seen in the upper part of the succession at Site 965.

\section{Rhodoliths}

Both intact (e.g., interval 160-965A-17X-1, 63-66 cm) and fragmentary, large $(>1 \mathrm{~cm}$ in size) rhodoliths (e.g., interval 107-965A$24 \mathrm{X}-1,34-37 \mathrm{~cm}$ ) are present, mainly in Hole 965A. Most rhodoliths have nuclei composed of micritic intraclasts, or rarely small bioclasts (e.g., interval 160-965A-6X-CC, 22-27 cm). Some of the best preserved examples are associated with relatively intact encrusting calcareous algae (e.g., intervals 160-965A-23X-1, 51-57 cm, and 160966F-11R-2, 85-91 cm).

Samples from the upper part of the succession at Site 965 contain numerous well-preserved small rhodoliths (1-2 cm in size). These are composed of structureless micritic cores, coated with fine microbial carbonate (e.g., interval 160-965A-5X-1- 36-39 cm). In addition, the micritic matrix in many samples is commonly pelletal or peloidal, reflecting a microbial origin (e.g., interval 160-965A-6-CC, 5-10 cm). In some cases intact, or nearly intact, small rhodoliths are mixed with variably disrupted and reworked calcareous algal fragments (e.g., interval 160-965A-21X-1, 39-45 cm). In rare cases, individual bioclasts and micritic intraclasts exhibit only very minor concentric microbial coatings (e.g., interval 160-965A-60-CC, 22$27 \mathrm{~cm})$. 

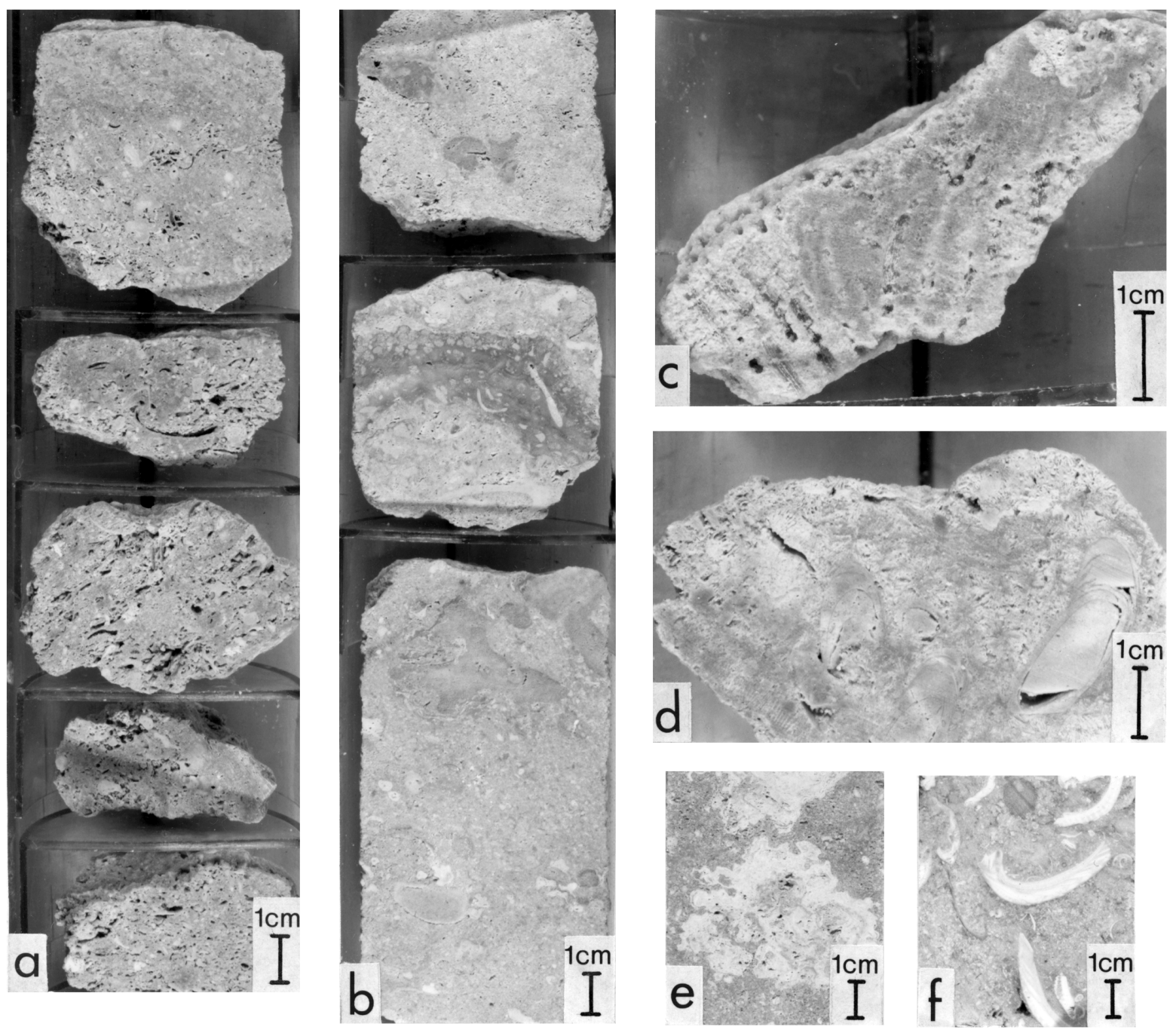

Figure 4. Photographs of sedimentary features in cores from Hole 966F. A. Common extensive dissolution porosity developed in packstone-grainstone (interval 160-966F-10R-1, 113-135 cm). B. Packstone-grainstone. Center: micritic crust that may represent a hardground; upper: burrows filled with lime mudstone; lower: bioturbated packstone-grainstone (interval 160-966F-11R-2, 15-28 cm). C. Partly dissolved fragment of poritid coral (interval 160-966F-12R-1, 3-9 $\mathrm{cm}$ ). D. Bioclastic limestone, bored to produce a cavity filled with micrite (interval 160-966F-12R-1, 15-18 cm). E. Red algal rhodolith (interval 160-966F17R-1, 48-54 cm). F. Disarticulated bivalves (interval 160-966F-10R-2, 69-75 cm).

\section{Corals}

Corals are mainly derived, poorly preserved, angular fragments mixed with calcareous algae, bivalve shells, and other allochems (e.g., interval 160-965A-23X-1, 8-11 cm). The dominant coral type is Porites sp. (Figs. 6D, 7D), both as encrusting types and as fragments of discrete coral heads (e.g., throughout Core 160-966F-11R). Locally, fragments of Tarbellastraea (interval 160-966F-11R-1, 60$65 \mathrm{~cm}$ ), or Siderasterea (e.g., interval 160-966F-12R-1, 13-20 cm), up to $5 \mathrm{~cm}$ in size, are present, mixed with rhodoliths. One coral fragment includes unusually well preserved Tarbellastraea (interval 160966F-11R-2, 45-51 cm; B. Rosen. pers. comm., 1996). Many of the coral fragments are bored (e.g., interval 160-966F-12X-1, 13-20 $\mathrm{cm})$.

\section{Molluscs}

Small bivalves are ubiquitous and range from scattered (interval 160-965A-16R-1, 86-91 cm) to densely packed, together with sparse occurrences of gastropods. Articulated shells are rarely present (interval 160-965A-12X-1, 13-20 cm). The shells in some cases are in a taphonomically settled position (i.e., concave downwards), with a micritic matrix between the shells (interval 160-966F-17R-4, 11-18 $\mathrm{cm}$ ). Most of the shells are disarticulated (Figs. 4F, 5C), often as fragments mixed with other bioclasts (e.g., interval 160-965A-5X-1, 0-4 $\mathrm{cm})$. Gastropod shells are rarely present in bivalve-rich horizons.

\section{Microfossils}

Benthic foraminifers range from scattered to locally abundant and are often mixed with coral-algal detritus (e.g., interval 160-966F$23 \mathrm{R}-1,34-41 \mathrm{~cm}$ ). Locally, tests are sufficiently numerous to define a weak stratification. Forms identified are miliolids (Figs. 6C, 7C) and very large benthic foraminifers of Lepidocyclina type; intervals 160-965A-26X-1, 25-28 cm, and 965A-6X-CC, 22-27 cm) (Emeis, Robertson, Richter, et al., 1996; I. Premoli-Silva, pers. comm., 1996). In addition, planktonic foraminifers are present within the finegrained matrix of many samples from Site 966 (e.g., interval 160- 

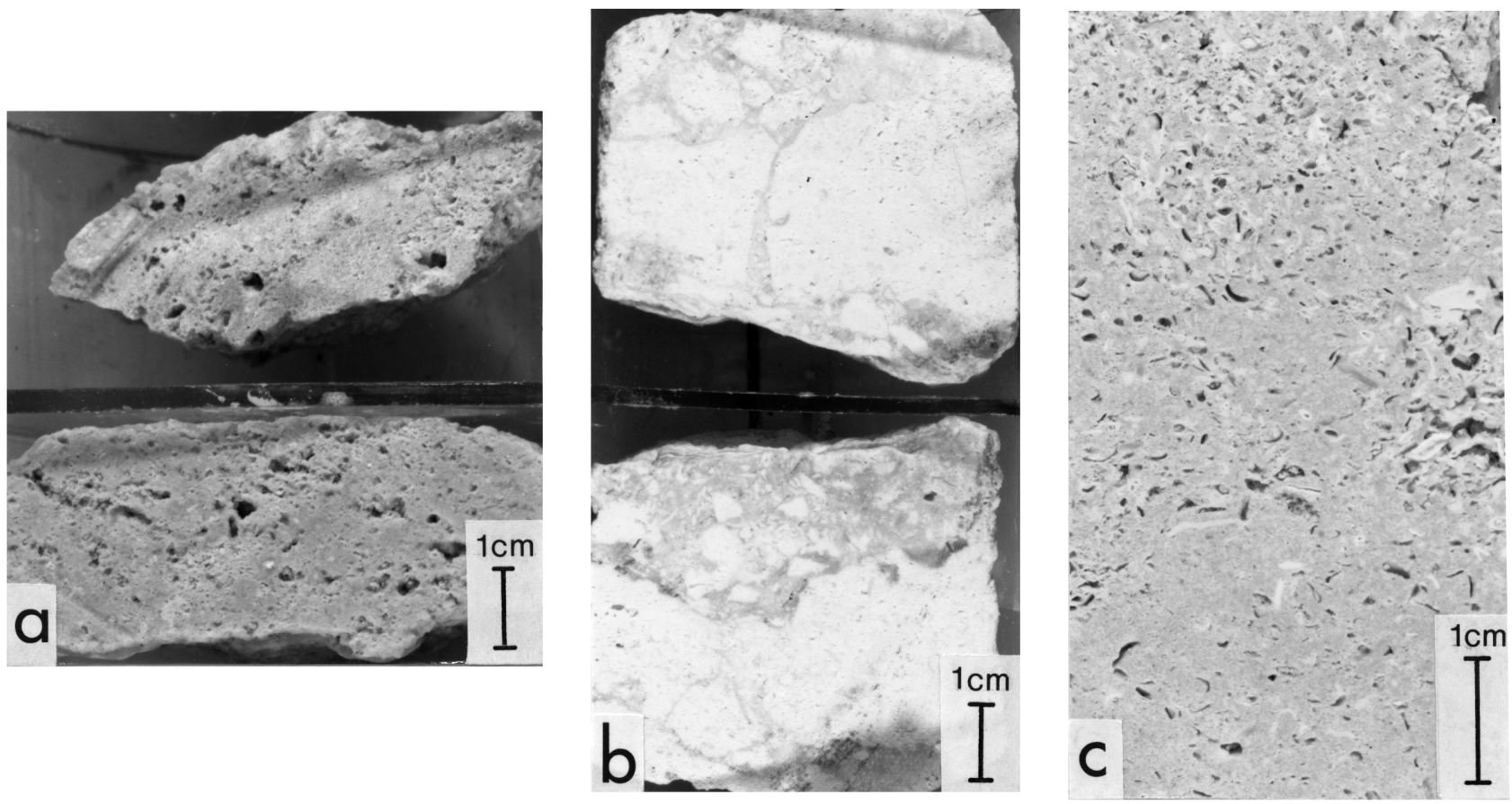

Figure. 5. Photographs of sedimentary features in cores from Hole 965A. A. Typical bioclastic limestone with high dissolution porosity (interval 160-965A-5X1, 25-30 cm). B. Evidence of early seafloor lithification; upper: brecciation of lithified limestone, possibly tectonically induced; lower: local reworking of angular clasts from a hardground (interval 160-965A-27X-1, 9-19 cm). C. Bioclastic limestone composed of mainly reworked shell fragments with secondary dissolution porosity (interval 160-965A-10X-1, 12-18 cm).

966F-11R; 65-70 cm; Fig. 6F), and in the upper part of the cored interval at Site 965 (e.g., interval 160-965A-6X-CC, 5-10 cm; Fig. 6C).

\section{Echinoderms}

Echinoderm plates and spines are scattered throughout the succession in both holes, especially in the coarser grained bioclastic facies (e.g., interval 160-965A-13X-1, 25-32 cm; Fig. 8A).

\section{Sponge Spicules}

Abundant sponge spicules were observed in a single sample from Site 965 (i.e., interval 160-965A-12X-1, 29-38 cm; Fig. 6E). Individual sponge spicules are preserved in the form of isotropic silica, both intact and as fragments. Petrographic evidence of recrystallization is absent.

\section{Intraclasts and Other Grains}

Scattered intraclasts of lime mud up to several centimeters in size were observed mainly in coarser grained, fragmental coral-microbial facies (e.g., interval 160-966F-10R-2, 76-81 cm). Thin-section studies revealed common isotropic grains of phosphatic material (e.g., interval 160-965A-6X-CC, 22-27 cm). In addition, local green (glauconite) grains are present.

\section{DIAGENESIS \\ Macroscopic Features}

Coarser grained bioclastic horizons are more calcite cemented (e.g., interval 160-966F-13R, 126-131 cm), than buff-colored, more muddy, finer grained layers. Cementation is patchy (e.g., interval
160-965A-20X-1, 25-33 cm). Very well-cemented horizons are present near the base of the recovered succession at Hole 965A (i.e., interval $160-965 \mathrm{~A}-26 \mathrm{X}-1,79-86 \mathrm{~cm})$. A lamination is locally defined by differential dissolution of individual grains. Development of secondary (i.e., moldic) porosity is widespread, commonly within bivalve and gastropod shells (e.g., interval 160-965A-10X-1, 11-14 $\mathrm{cm})$. The coarsest grained intervals generally show the most dissolution. Benthic foraminifers have also rarely undergone dissolution (e.g., interval 160-966F-7R-1, 10-13 cm). Corals are commonly dissolved and calcitized. Calcareous algae are relatively resistant to diagenetic alteration, whereas other carbonate material is mainly recrystallized (e.g., interval 160-966F-15R-1, 62-65 cm).

Samples from Hole 965A are commonly more recrystallized than those in Hole 966F, especially near the base of the cored intervals, with variably preserved grains set in a micritic matrix. Marked variation in diagenetic alteration is seen within individual thin sections (e.g., interval 160-965A-5R-1, 0-4 cm). Dark gray, or greenish gray, neomorphosed carbonate (dolomite?) was observed near the top of the succession at Site 966F (interval 160-966F-6R-CC, 23-30 cm). In addition, minor secondary sulfide was noted (interval 160-966F$8 \mathrm{R}-8-12 \mathrm{~cm}$ ). This was associated with a green color. In addition, small fragments of replacement chert were locally noted in cores (e.g., throughout Core 160-966F-15R). Chert is rarely recovered by drilling and is assumed to be relatively abundant in some intervals (Fig. 3). Microcrystalline silica is locally observed to replace oncolites or corals (e.g., intervals 160-966F-13R-1, 126-133 cm, and $14 \mathrm{R}-1,95-100 \mathrm{~cm})$.

Minor evidence of tectonic brecciation and microfaulting (e.g., throughout Section 160-966F-20R-1) was also locally observed at Site 965 (i.e., Core 160-965A-27X; Emeis, Robertson, Richter, et al., 1996; Fig 7A). Sporadic small fractures are filled with calcite spar (e.g., intervals 160-965A-27X-1, 34-37 cm, and 160-966F-21R-1, $8-11 \mathrm{~cm})$. 



Figure 6. Photomicrographs of thin sections of samples. A. Rhodolith in bioclastic limestone (interval 160-965A-17X-1, 63-66 cm). B. Detail of rhodolith (interval 160-965A-23X-1, 51-57 cm). C. Benthic foraminifer with cavities filled with fine calcite spar (interval 160-965A-16X-1, 25-28 cm). D. Detail of a poritid coral. The skeletal aragonite is replaced by spar, whereas interstices are filled with micrite (interval 160-966F-11R-2, 45-51 cm). E. Sponge spicule (opal) in spicule (interval 160-965A-12X-1, 29-38 cm). F. Planktonic foraminifer within lime mud (interval 160-965A-6X-CC, 5-10 cm).

\section{Alteration of Grains}

Micritic envelopes are ubiquitous and are especially well developed on bivalve fragments (e.g., interval 160-966F-8R-1, 4-8 cm; Fig. 4D). Individual echinoderm plates and spines additionally show evidence of boring that forms cavities filled with micrite (interval 160-966-10R-2, 76-81 cm). Borings are also observed within calcareous algae (e.g., interval 160-966F-11R-2, 85-91 cm).

\section{Early Cements}

Early cements were noted in several thin sections of coarsegrained bioclastic grainstone from Site 966 (e.g., interval 160-966F$10 \mathrm{R}-2,76-81 \mathrm{~cm}$ ). Primary porosity (i.e., both intergranular and intra-skeletal) is largely filled by fibrous carbonate. Individual voids are lined with acicular, isopachous, fringing cement (Fig. 8B). Some cavities are entirely filled with cement of this type. 

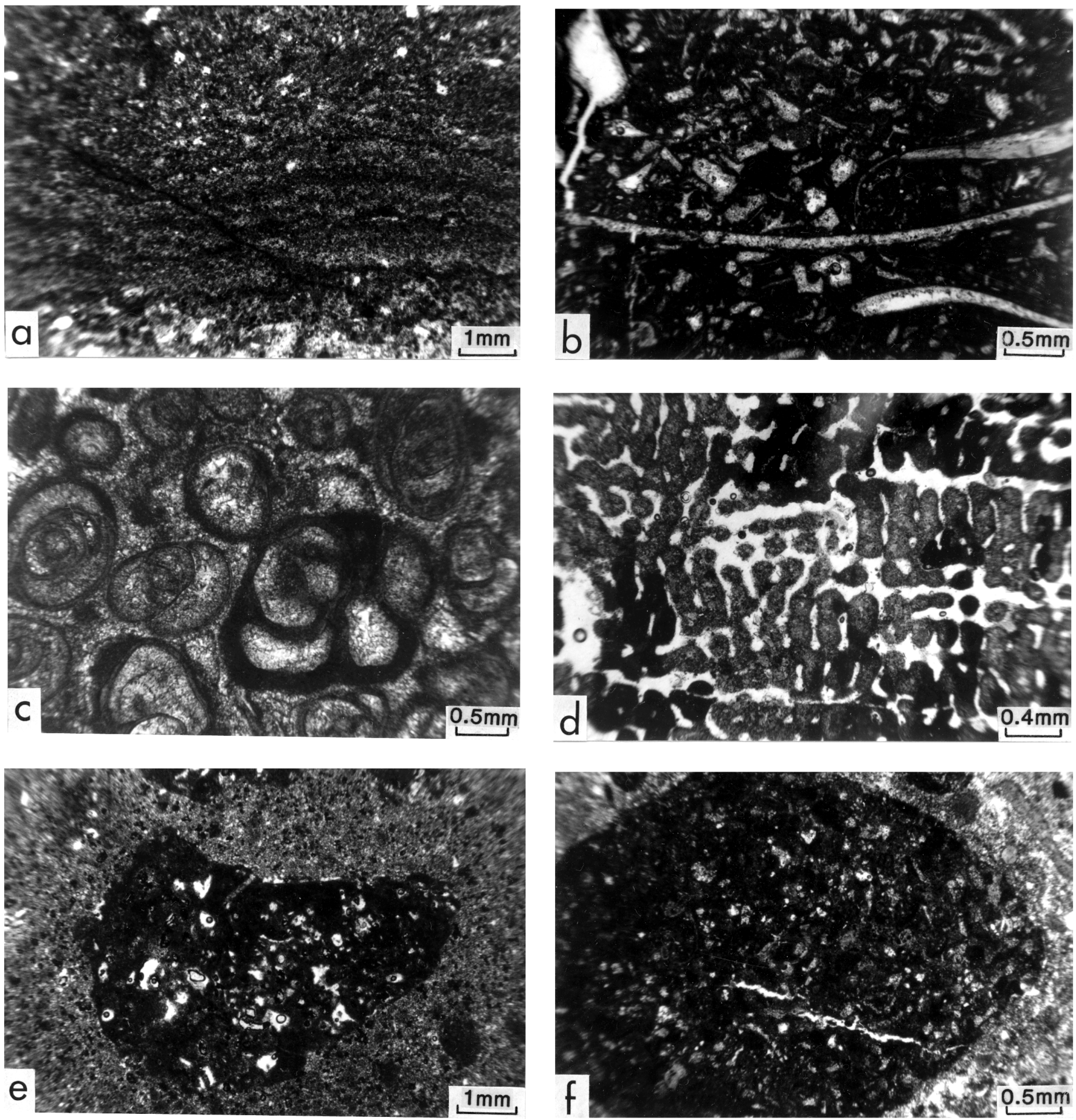

Figure 7. Photomicrographs of thin sections of samples. A. Lime mudstone cut by small fractures (interval 160-965A-26X-1, 79-81 cm). B. Reworked bioclastic limestone with bivalve shell fragments (interval 160-966F-8R-1, 8-12 cm). C. Reworked bioclastic limestone with densely packed miliolines. Note the calcite spar cement, both within and between tests (interval 160-966F-10R-2, 76-81 cm). D. Detail of poritic coral; aragonite skeleton is replaced by spar, whereas interstices are filled with micrite (interval 160-966F- 11R-1, 60-65 cm). E. Intraclast within packstone (interval 160-966F-11R-2, 45-51 cm). F. Intraclast of fine packstone (interval 160-966F-11R-2, 45-51 cm).

\section{Dissolution Porosity}

Both the grains and the matrix have undergone extensive dissolution (e.g., interval 160-965A-5X-1, 0-4 cm; Figs. 4A, 4C, 8C, D). The shells of aragonitic fossils, especially bivalves, have dissolved and left a fabric supported by micritic envelopes (e.g., interval 160965A-6X-CC, 5-10 cm). Bivalves are mainly neomorphosed (e.g., interval 160-965A-6X, 22-27 cm). In some cases the matrix appears to have been preferentially dissolved (Fig. 8D), Almost the entire primary fabric is obscured by the development of dissolution porosity in some samples (e.g., interval 160-965A-20X, 25-33 cm).

\section{Later Stage Cements}

The walls of many solution cavities are lined with isopachous calcite crystals leaving many voids. These crystals range from short, 

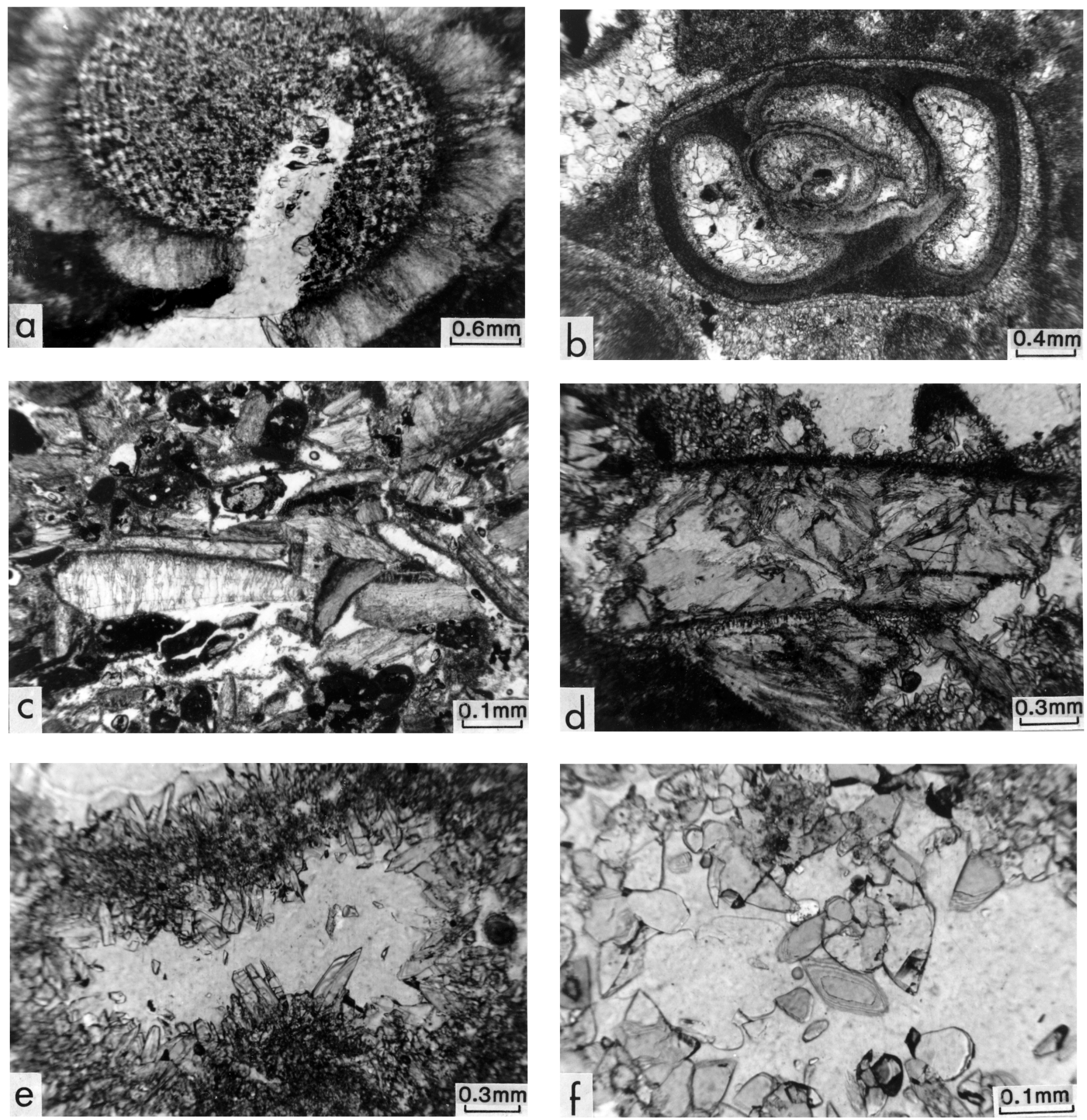

Figure 8. Photomicrographs of diagenetic features. A. Echinoderm spine with sparry calcite overgrowth that was later fragmented (interval 160-966F-10R-2, 76-81 cm). B. Milioline within biomicrite. Interskeletal voids (e.g.,within tests) are filled with calcite spar (interval 160-966F-8R-1, 8-12 cm). C. Packstone with numerous bivalve shell fragments. The shell fragments were broken during reworking and were then altered, with development of micritic envelopes, followed by partial to complete dissolution of shell interiors and filling with sparry calcite (interval 160-966F-10R-2, 76-81 cm). D. Detail of broken bivalve shell fragment. The fragment was later altered with development of a micritic envelope, and was then dissolved and filled with calcite spar. The micritic matrix was also largely dissolved and replaced by spar (interval 160-966F-10R-2, 76-81 cm). E. Cavity within biomicrite that was later partly filled with prismatic calcite spar (interval 160-965A-20X-1, 25-33 cm). F. Detail of rhombic spar partly filling cavity. The secondary dissolution porosity probably developed in response to meteoric water influx during Messinian emergence (interval 160-965A-9H-2, 75-79 cm). 
stubby crystals, to prismatic crystals, and exhibit a palisade-type fabric (Fig. 8E). In addition, where solution cavities have formed within the matrix, these too show a similar type of partial to complete fill (e.g., interval 160-965A-5X-1, 36-39 cm).

The interiors of some dissolution cavities that remained empty after precipitation of isopachous spar are partly to totally filled with blocky, equant calcite spar (e.g., interval 160-966F-20X-1, 25-33 $\mathrm{cm}$; Fig. 8B). Calcite spar lines or fills cavities. The moldic porosity within coral (e.g., Porites sp.) is partly to completely filled with calcite spar that is commonly rhombic (e.g., interval 160-966F-11R-1, $24-28 \mathrm{~cm}$; Fig. 8F).

The micritic matrix is commonly partly to totally replaced by microspar (e.g., interval 160-965A-26X-1, 25-28 cm). Some larger cavities contain large spar crystals (e.g., intervals 160-965A-19X-1, 19-24 cm, and 160-965A-22X-1, 0-5 cm). Rhombic carbonate is also observed locally within a partly recrystallized micritic matrix (e.g., interval 160-965A-20X-1, 25-33 cm). Coarsely crystalline rhombic spar dominates the lower part of the cored interval at Site 966 and almost entirely destroys the original textures (e.g., intervals 160-966F-11R-2, 11-16 cm, 160-966F-11R-2, 85-91 cm, and 160$966 \mathrm{~F}-16 \mathrm{R}-1,86-89 \mathrm{~cm})$. X-ray diffraction shows that this heavily recrystallized carbonate is dolomite (see subsequent section).

\section{Syntaxial Overgrowths on Echinoderm Plates}

Echinoderm plates and spines are commonly overgrown by syntaxial calcite spar (Evamy and Shearman, 1965; e.g., interval 160966F-10R-2, 76-81 cm; Fig. 8A). In one case, a syntaxial overgrowth on a large spine was developed only in that part of a thin section that had undergone extensive dissolution and spar cementation, whereas no overgrowth was present in the adjacent area where biomicrite was preserved.

\section{Compaction Features}

Many bioclasts show evidence of compaction and fragmentation after development of micritic envelopes, but before filling of dissolution cavities with calcite spar. Samples from Hole 966F show more evidence of compaction than those from Hole 965A. Compaction is most evident where disarticulated bivalve shells are tightly packed and imbricated. Imbricated shells were fractured, then dissolved, leaving molds that were later variably filled with sparry calcite (interval 160-966F-7R-1, 10-13 cm). The shell dissolution clearly took place at a relatively early stage, as delicate molds are unaffected. In addition, laminated calcareous algae are also commonly fragmented as a result of compaction (e.g., intervals 160-965A-21X-1, 39-45 cm, 23X-1, 51-57 cm, and 160-966F-16R-1, 86-91 cm).

\section{Pressure Dissolution}

Minor pressure dissolution is locally present (e.g., interval 160965A-27X-1, 8-13 cm). An en echelon array of pressure dissolution seams was locally observed in the lower part of the interval cored at Hole 966F (interval 160-966F-14R-1, 95-100 cm). This may be related to faulting rather than simply to compaction (Fig. 7A).

\section{Silica Diagenesis}

Several samples (e.g., interval 160-966F-6R-CC, 23-30 cm) from near the top of the cored interval at Hole $966 \mathrm{~F}$ exhibit abundant solution porosity, partly filled with a relatively soft brown substance that was identified as opal, based on shipboard X-ray diffraction analysis (Emeis, Robertson, Richter, et al., 1996). In thin section, the material is entirely isotropic. The source of the silica may have been sponge spicules that are locally abundant in Hole 965A, but were not observed in Hole 966F.

\section{X-RAY DIFFRACTION ANALYSIS}

Whole-rock X-ray diffraction was conducted on 26 samples from Hole 965A (Table 1) and 19 samples from Hole 966F (Table 2). Quantitative analysis of the dolomite content was also conducted on selected samples.

Samples from Cores 160-965A-1X through 17X contain variable mixtures of calcite and dolomite (Table 1). The more deeply buried lithologies, deeper than $150 \mathrm{mbsf}$ in Hole 966A, have undergone

Table 1. Whole-rock X-ray diffraction data for selected samples from Hole 965A.

\begin{tabular}{|c|c|c|}
\hline $\begin{array}{l}\text { Core, section, } \\
\text { interval }(\mathrm{cm})\end{array}$ & Mineralogy & $\begin{array}{c}\text { Estimated } \\
\text { dolomite (\%) }\end{array}$ \\
\hline \multicolumn{3}{|l|}{ 160-965A- } \\
\hline $5 X-1,1,0-4$ & CALCITE, aragonite & - \\
\hline $5 X-1,36-39$ & CALCITE, aragonite & - \\
\hline $6 X-1,5-10$ & CALCITE, aragonite & - \\
\hline $6 X-1,22-27$ & CALCITE, aragonite & - \\
\hline $8 X-1,10-16$ & CALCITE & 0 \\
\hline $9 X-1,56-60$ & CALCITE, aragonite & - \\
\hline $10 X-1,11-14$ & CALCITE only & - \\
\hline $11 X-1,0-7$ & CALCITE only & - \\
\hline $12 \mathrm{X}-1,29-38$ & CALCITE only & - \\
\hline $13 \mathrm{X}-1,25-32$ & CALCITE aragonite & - \\
\hline $14 \mathrm{X}-1,34-40$ & CALCITE, aragonite & - \\
\hline $15 X-1,40-48$ & CALCITE only & - \\
\hline $16 \mathrm{X}-1,12-14$ & CALCITE only & - \\
\hline $19 X-1,19-24$ & CALCITE, DOLOMITE & 45 \\
\hline $20 \mathrm{X}-1,25-33$ & CALCITE, DOLOMITE & 20 \\
\hline $21 X-1,39-45$ & DOLOMITE, dolomite, calcite & 99 \\
\hline $22 X-1,0-5$ & DOLOMITE, CALCITE & 70 \\
\hline $23 \mathrm{X}-1,8-11$ & CALCITE, DOLOMITE & 30 \\
\hline $23 X-1,51-57$ & DOLOMITE, calcite & 99 \\
\hline $24 X-1,34-37$ & DOLOMITE, CALCITE & 99 \\
\hline $24 X-1,55-61$ & DOLOMITE, calcite & 99 \\
\hline $26 X-1,25-28$ & CALCITE, dolomite & 4 \\
\hline $26 \mathrm{X}-1,79-86$ & CALCITE, Dolomite & 10 \\
\hline $27 \mathrm{X}-1,8-13$ & CALCITE, Dolomite & 25 \\
\hline $27 X-1,34-37$ & CALCITE, Dolomite & 20 \\
\hline $27 \mathrm{X}-1,43-49$ & CALCITE, DOLOMITE & 30 \\
\hline
\end{tabular}

Notes: Major constituent in capitals (e.g., DOLOMITE), minor constituent in initial capitals (e.g., Dolomite), and trace constituent in lower case (e.g., dolomite). Selected samples were analyzed for approximate abundance of dolomite, using a method in which samples were spiked with pure dolomite and calibrated to allow determination of absolute abundance (reported in percent).

Table 2. Whole-rock X-ray diffraction data for selected samples from Hole 966F.

\begin{tabular}{llc}
\hline $\begin{array}{c}\text { Core, section, } \\
\text { interval }(\mathrm{cm})\end{array}$ & \multicolumn{1}{c}{ Mineralogy } & $\begin{array}{c}\text { Estimated } \\
\text { dolomite }(\%)\end{array}$ \\
\hline 160-966F- & & \\
6R-CC, 23-30 & DOLOMITE, calcite & 97 \\
8R-1, 8-12 & CALCITE, aragonite, quartz & - \\
8R-1,91-99 & CALCITE, quartz, albite & - \\
10R-2, 76-81 & CALCITE, Aragonite, dolomite & - \\
11R-2, 11-16 & CALCITE, Dolomite & 9 \\
11R-1, 24-28 & CALCITE only & - \\
11R-2, 45-51 & DOLOMITE, Calcite & - \\
11R-1, 60-65 & CALCITE only & - \\
11R-1, 65-70 & CALCITE, aragonite & 63 \\
11R-2, 85-91 $97-104$ & DOLOMITE, CALCITE & 66 \\
13R-1, 126-133 & CALCITE, aragonite & 98 \\
14R-1, 22-27 & DOLOMITE, CALCITE & -100 \\
15R-1, 62-65 & DOLOMITE, calcite & - \\
16R-1, 86-91 & DOLOMITE, calcite & $\sim 100$ \\
17R-4, 11-18 & DOLOMITE only & 46 \\
19R-2, 35-39 & DOLOMITE, calcite & - \\
21R-1,8-11 & DOLOMITE, CALCITE & - \\
23R-1, 63-65 & CALCITE, dolomite & \\
\hline
\end{tabular}

Notes: Major constituent in capitals (e.g., DOLOMITE); minor constituent, initial capitals (e.g., Dolomite), trace constituent in lower case (e.g., dolomite). Selected samples were analyzed for approximate abundance of dolomite, using a method in which samples were spiked with pure dolomite and calibrated to allow determination of absolute abundance (reported in \%). 
more advanced diagenesis. This interpretation is also supported by interpretation of the wireline logs (Major et al., Chap. 38, this volume). Several of the samples of calcareous algal limestone (e.g., interval 160-965A-24X-1, 34-37 cm) are composed mainly of dolomite, whereas samples of wackestone, grainstone, and packstone commonly contain only calcite with, in addition, aragonite above 150 mbsf. However, above 130 mbsf (Cores 160-965A-15X through 5X), samples are dominantly calcite, but with common traces of aragonite and only rare dolomite.

In Hole 966F, dolomite is patchily developed throughout the succession up to around $110 \mathrm{mbsf}$. The majority of the samples below 150 mbsf are dominated by dolomite with minor calcite, or calcite with subordinate calcite. Dolomite ranges from $9 \%$ to $100 \%$ of individual samples. Aragonite is a minor constituent above $160 \mathrm{mbsf}$, although one sample consists entirely of calcite. Quartz and feldspar were detected in several samples near the top of the succession $(\sim 130$ mbsf).

\section{ELECTRON MICROPROBE ANALYSIS}

To test the mineralogic identifications based on thin section and XRD analysis, 25 samples from Hole $966 \mathrm{~F}$ were analyzed using an electron microprobe (Table 3 ). The results show that nearly all the bioclasts and cement are composed of low-magnesian calcite. $\mathrm{MgO}$ values typically range up to $2.0 \%$ within bioclasts. One sample of recrystallized bivalve shell contains no detectable $\mathrm{MgO}$. In addition, samples of fibrous cement, syntaxial overgrowths, and later-stage void-filling rhombic spar are also composed of low-magnesian calcite. Calcareous algal bioclasts contain up to $3.2 \% \mathrm{MgO}$. By contrast, samples of finely crystalline spar are almost entirely composed of dolomite, in agreement with the XRD results. Individual calcareous algal bioclasts within the latter sample are also dolomitized.

In addition, two samples were analyzed from clasts in the overlying mass-flow unit of early Pliocene age in Hole 966F. These clasts are interpreted as derived from the underlying Miocene limestone (Emeis, Robertson, Richer, et al., 1996; Robertson, Chap. 37, this volume). Sparry cements in these clasts are again composed of low-magnesium calcite.

\section{INTERPRETATION \\ Depositional Processes}

The carbonate successions recovered from the successions at Sites 965 and 966 record Miocene shallow-marine sedimentation on a relatively flat, carbonate platform. The local presence of hardgrounds is suggestive of fluctuations in sedimentation rate, with lithification taking place during periods of reduced deposition or nondeposition. The time span of preserved carbonate deposition is unknown, but it is assumed that at least part of the deposition took place in the late Miocene, based on the preliminary strontium isotopic results from Site 965.

Most of the lithological variation at both sites can be explained in terms of repeated small-scale cycles of flooding and regression. Such events could be caused by tectonic subsidence, eustatic sea-level rise, or be autocyclic (i.e., related to sedimentation) processes. Bioclastic material formed in a relatively high-energy reef environment and was then reworked into a mud-dominated setting, where microbial mats locally developed. Bivalve shells are commonly winnowed and locally exist as imbricated shells in a hydrodynamically stable position. Where benthic foraminifers are abundant, these perhaps formed shoals adjacent to reef build ups.

At Site 965 , the existence of clasts of coral up to $5 \mathrm{~cm}$ in size points to a near-reef depositional setting. This is supported by the FMS data that indicate the existence of coarse clastic material around 195-205 mbsf. The interbedded rhodoliths were probably also reworked into a carbonate mud dominated setting. The presence of shell-rich grainstones near the top of the cored intervals also indicate winnowing by currents. Much of the coral-microbial material at Site 966 is finer grained and more fragmented, which suggest a slightly more distal depositional setting. This interpretation is supported by the common occurrence of planktonic foraminifers throughout the succession at Site 966, whereas at Site 965, lime mud is less abundant, and planktonic foraminifers are common only in the higher levels of the cored succession. However, coarse clastic material is also present at Site 966 around 145-150 mbsf, which suggests that a reef was developed close to this site at one time.

At both Sites 965 and 966, minor terrigenous quartz, feldspar, and muscovite were observed; this is presumably of windblown origin.

Table 3. Electron microprobe analysis of selected samples of carbonates from Site 966.

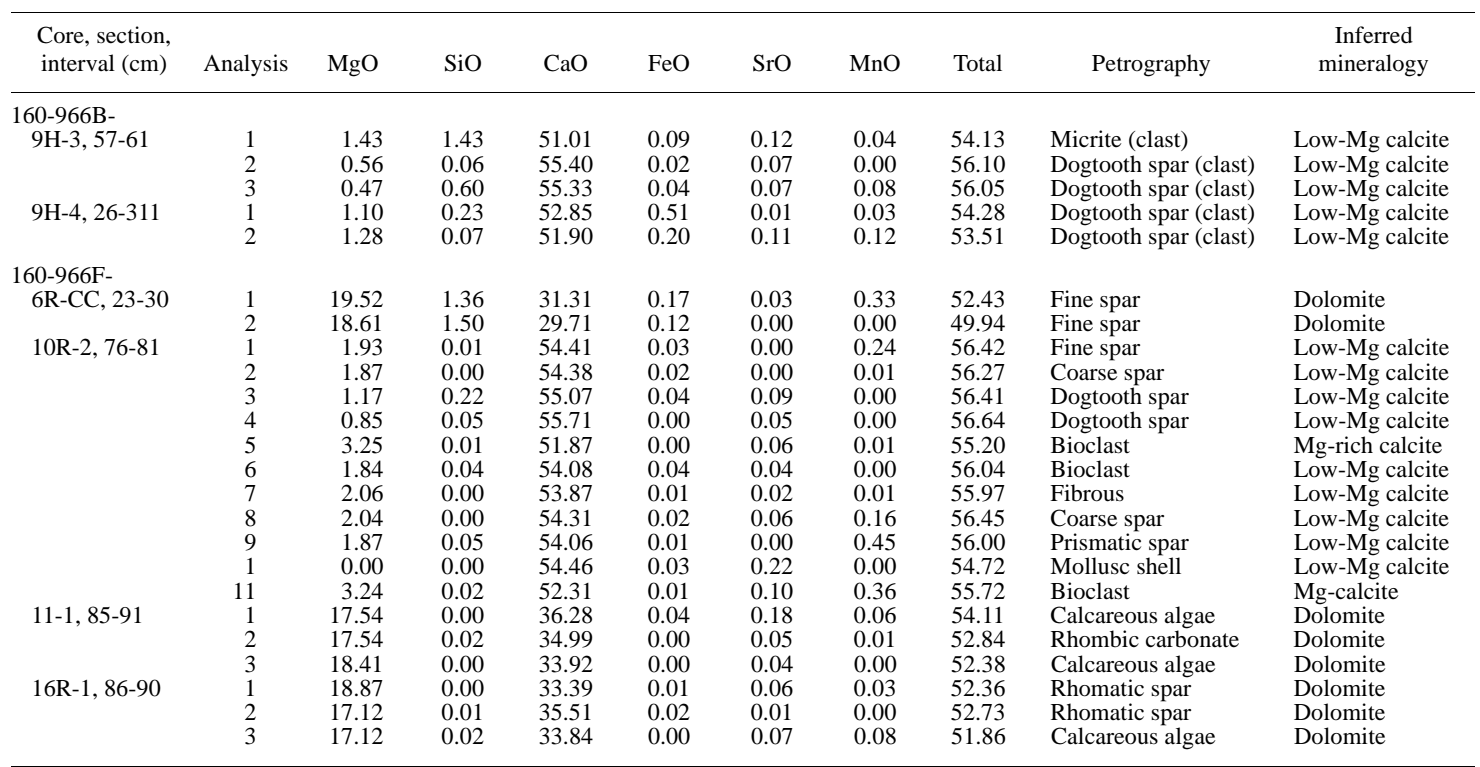

Notes: Calculated as weight percent oxide. The analysis was carried out using a Cambridge Instruments Microscan Mark 5 wavelength dispersive electron microprobe. Samples were prepared as polished, uncovered thin sections that were carbon coated under vacuum. Silicate, oxide, and pure metal standards were used for calibration. Operating conditions: accelerating potential $=20 \mathrm{kV}$; beam current $=30$ nanno a; count time $=40 \mathrm{~s}$ for peaks and $20 \mathrm{~s}$ for background; and beam diameter $=2 \mu \mathrm{m}$. 
The obvious source is North Africa, as little quartz is present in the sedimentary succession of Cyprus to the north (e.g., Robertson et al., 1991).

The shallow-water carbonates of Sites 965 and 966 are inferred to have formed in a carbonate platform setting adjacent to coral reefs rich in calcareous algae. It is likely that the entire surface of the Eratosthenes Seamount was capped by carbonate depositional environments, principally reefal and lagoonal settings. An origin of fringing reefs around a lithified core is unlikely in view of the absence of reworked lithoclasts of pelagic carbonate derived from the underlying Eocene pelagic carbonate succession.

\section{Diagenesis}

Thin-section studies reveal a consistent series of diagenetic events applicable to both Sites 965 and 966. The earliest diagenetic events recorded are borings, particularly of echinoderm plates and calcareous algae, and the formation of micritic envelopes, especially around bivalve shells, combined with some early compactive fracturing of shells. Early-stage fibrous cements are rich in inclusions and were originally either aragonite or high-magnesian calcite, but are now low-magnesian calcite. These early cements are preserved only rarely, as fill of primary intergranular porosity and cavities within bioclasts. Comparison with well-documented modern and ancient examples (e.g., Aissaoui, 1988; Tucker and Bathurst, 1990a, 1990b, 1990c) indicate that similar fibrous carbonate is of marine origin. Such marine cement may well have developed widely, but, if so, was later mainly dissolved.

Development of moldic (i.e., secondary) dissolution porosity is ubiquitous. Aragonite was preferentially dissolved (e.g., corals). Dissolution was, however, patchy and has preferentially affected porous packstone-grainstone horizons. Comparisons with modern and ancient examples suggest this dissolution resulted from flushing by meteoric waters (Purser, 1969; Land, 1970; James et al., 1988). The Eratosthenes Seamount was subaerially exposed during the Messinian salinity crisis, as indicated by the local presence of inferred paleosols at Site 965 and the seismic evidence that shows the M reflector wedging out against the upper levels of the Eratosthenes Seamount (e.g., Limonov et al., 1994). Evaporites are inferred to be present at Site 967, on the lower northern slope of the Eratosthenes Seamount, based on pore fluid, geochemical and wireline log evidence (Emeis, Robertson, Richter, et al., 1996).

The dissolution porosity is variably filled with calcite spar. However, many primary cavities remain largely free of cement. The earlier void-filling cement is commonly a sparse stubby isopachous cement, that grades into scalenohedral spar and probably formed in vadose and/or shallow burial diagenetic settings (e.g., Tucker and Bathurst, 1990a, 1990b, 1990c). Such cementation is subject to climatic influence. In warm, humid settings, much, or all, of the solution porosity is liable to be filled by calcite spar cement in the vadose zone, whereas in arid or semi-arid settings, interstitial fluid flow is reduced and only minimal calcite spar may develop (e.g., Hird and Tucker, 1988). The Eratosthenes Seamount cements are of the second type, with the implication that the climate during the Messinian time of exposure was arid or semi-arid.

Remaining porosity was later partly removed by the precipitation of blocky calcite spar cement. Textural evidence shows that this cementation followed extensive compaction and the cement is thus of burial, rather than vadose origin (e.g., Tucker and Bathurst, 1990a, $1990 \mathrm{~b}, 1990 \mathrm{c})$. The later stages of cementation involved precipitation of isolated rhombic calcite crystals that are especially well developed within moldic porosity, that was formed by dissolution of poritid corals.

Dolomitization is restricted to the lower part of the cored succession in Hole 965A, but is more patchily distributed throughout the succession in Hole 966F. The dolomite developed relatively late in the diagenetic history as it overprints and commonly completely replaces the primary textures. Similar dolomitization was noted in Mio- cene reefs of southern Cyprus (Follows, 1992). Several possible origins can be considered, each related to a mixing zone of waters of differing salinity that developed during the Messinian salinity crisis and subsequent refilling of the Mediterranean Sea:

1. The dolomite was developed in circulating seawater ahead of the mixing zone. This could occur if seawater flushed the reef carbonate related to Messinian emergence of the Eratosthenes Seamount.

2. The dolomite was related to mixing of normal seawater with hypersaline waters during the transgression that terminated the salinity crisis.

3. The dolomite relates to mixing of marine water with meteoric waters associated with the transgression. The second and third options are more probable than the first, as the dolomite does not itself show evidence of meteoric water dissolution. However, the second option is less likely than the third, as the seamount formed a high that was isolated from precipitation of thick evaporite in the adjacent basin (although localized hypersalinity might have developed within a former lagoon on the seamount). Stable isotopic data are needed to shed more light on the origin of the dolomite.

Sometime during burial diagenesis the lower part of the interval cored at Site 966 underwent minor tectonic disruption that involved limited pressure dissolution and fault displacement. The deformation at Site 966 could have acted to enhance carbonate recrystallization relative to Site 965 .

\section{Tectonic Model}

An isolated, submerged, carbonate platform existed in the area of the Eratosthenes Seamount before the Miocene (Emeis, Robertson, Richter, et al., 1996; Robertson, Chap. 32, this volume). Reef growth was initiated following an uplift of around $1 \mathrm{~km}$ that was accompanied by nondeposition or erosion. The cause of the uplift remains unclear. One possibility is that regional compression resulted in crustal flexure and thus uplift. The compression was possibly related to the onset of the present cycle of northward subduction of the Eastern Mediterranean seafloor, including Eratosthenes, beneath the Cyprus active margin to the north (Robertson et al., 1996). The uplift was followed by subsidence (Whiting, Chap. 39, this volume), thus promoting the conditions required for reef development. Build-up was also influenced by relative sea-level changes (i.e., related to local tectonics or eustatic sea-level change) that provided the accommodation space for carbonate build up.

\section{REGIONAL COMPARISONS}

The Eratosthenes Miocene limestones are comparable with shallow and deeper water limestones that were previously dredged from the western margin of the Eratosthenes Seamount. Comparisons can also be made with Miocene carbonates, including examples in southern Cyprus, southern Turkey, Israel and elsewhere in the Mediterranean region (see articles in Franseen et al., 1996).

\section{Dredged Eratosthenes Sample}

Dredging during the cruise of the Akademik Nikolaj Strakhov recovered limestone from the western scarp of the seamount (Station 31 at $33^{\circ} 42.1^{\prime} \mathrm{N}$ and $32^{\circ} 27.4^{\prime} \mathrm{E}$; Krasheninnikov et al., 1995). The sample appears to have been broken from bedrock, which is in contrast to other dredged material (including granite and basalt?) that was probably not in situ (i.e., most likely it was ship's ballast). Most of the limestone is composed of moderately recrystallized fragments of corals, molluscs, echinoderm spines, and foraminifers. Secondary porosity is well developed, with incomplete filling of dissolution porosity. 
The shallow-water limestone is coated with a layer of Fe-Mn oxides, which is covered by a crust of fine-grained limestone that contains Orbulina universa, Globerigerina sp., and globigerinoids. The shallow-water limestone was inferred to be of Late Cretaceous age, based on a purely lithological comparison with shallow-water limestones in Syria (Krasheninnikov et al., 1995). In fact, shallow-water limestones of Triassic to Miocene age are ubiquitous on land around the Eastern Mediterranean. Consequently, it is more probable that the dredged limestones are of Miocene age. This is supported by the close lithological similarities with the limestones drilled at Sites 965 and 966. Also, the diagenesis of all three occurrences is similar, with extensive, inferred meteoric-water diagenesis. If correctly interpreted, the dredged sample extends the known distribution of Miocene shallowwater limestone on the Eratosthenes Seamount. Also, the presence of "large corals" in the dredged sample suggests a proximal reef setting. The Fe-Mn crust probably accumulated during a depositional hiatus. Pelagic carbonate was drilled directly above lower Miocene limestones at Sites 966 and 967, suggesting a Pliocene age for this pelagic carbonate crust.

\section{Southern and Western Cyprus \\ Lower Miocene Reefs}

Miocene limestones are well exposed in southern and western Cyprus around the margins of the Troodos ophiolitic massif, and the Akamas Peninsula in northwestern Cyprus (Figs. 9, 10). The reef limestones are represented by the lower Miocene Terra Member and the upper Miocene Koronia Member, both of the Miocene Pakhna Formation (Follows, 1990; Follows and Robertson, 1990). The distribution of the Terra Member is localized to a small area of southeastern Cyprus and in the Akamas Peninsula, whereas the Koronia Member is more widely distributed around the periphery of the Troodos Massif (Fig. 10). In western Cyprus, the Terra Member is underlain by Oligocene pelagic carbonates of the Lefkara Formation and over- lain by Middle Miocene pelagic chalks of the Pakhna Formation. The Terra Member rests on chalk of the Lefkara Formation, dated as Aquitanian to mid-Burdigalian, as determined from the co-occurrence of the benthic foraminifers Eulepidina, Spiroclypeus, Miogypsinoides, Lepidocyclina, Miogypsina, and Miolepidocyclina burdigalensis.

In western Cyprus, the Terra Member reef limestones developed in an arcuate pattern that was controlled by the paleotopography of an Akamas "high" to the west and the western margin of the Troodos ophiolitic massif to the east. The reef limestones locally overstep on to a basement of Mesozoic "melange" (the Mamonia Complex). This area underwent differential uplift and erosion before reef-limestone deposition. The individual reefs of the Terra Member comprise small framestone structures that are scattered through lime mudstone and other intra-reef sediments. The reef framework is composed of massive and branching corals, encrusting organisms, solitary corals, calcareous algae, bryozoans, serpulids, foraminifers, and molluscs. Porites sp., Favia sp., and Favites sp. dominate the frame structures along with other coral morphologies (e.g., Actinastrea sp. and Acropora sp.). Intra-reef sediment is mainly coarse bioclastic debris. The reef tract was bordered by a northward-dipping, distally steepened carbonate ramp on which debris flows accumulated, including large benthic foraminifers and rhodoliths, passing into mainly pelagic carbonate in a deeper water setting further from the reefs.

In southeastern Cyprus, the reefs of the Terra Member rest on Cretaceous melange and Paleogene chalks of the Lefkara Formation and are, in turn, overlain by chalks that are dated as middle Miocene, based on calcareous nannofossils (Follows, 1992; Follows et al., 1996). The Terra Member reefs in southeastern Cyprus developed on a relatively stable, flat-topped high that was possibly fault bounded. Within the Terra Member in southeastern Cyprus, coral-dominated patch reefs, together with calcareous algal deposits, pass laterally into benthic foraminiferal packstones and grainstones, lime mudstones, and then into pelagic carbonates. Reworked material includes frag-

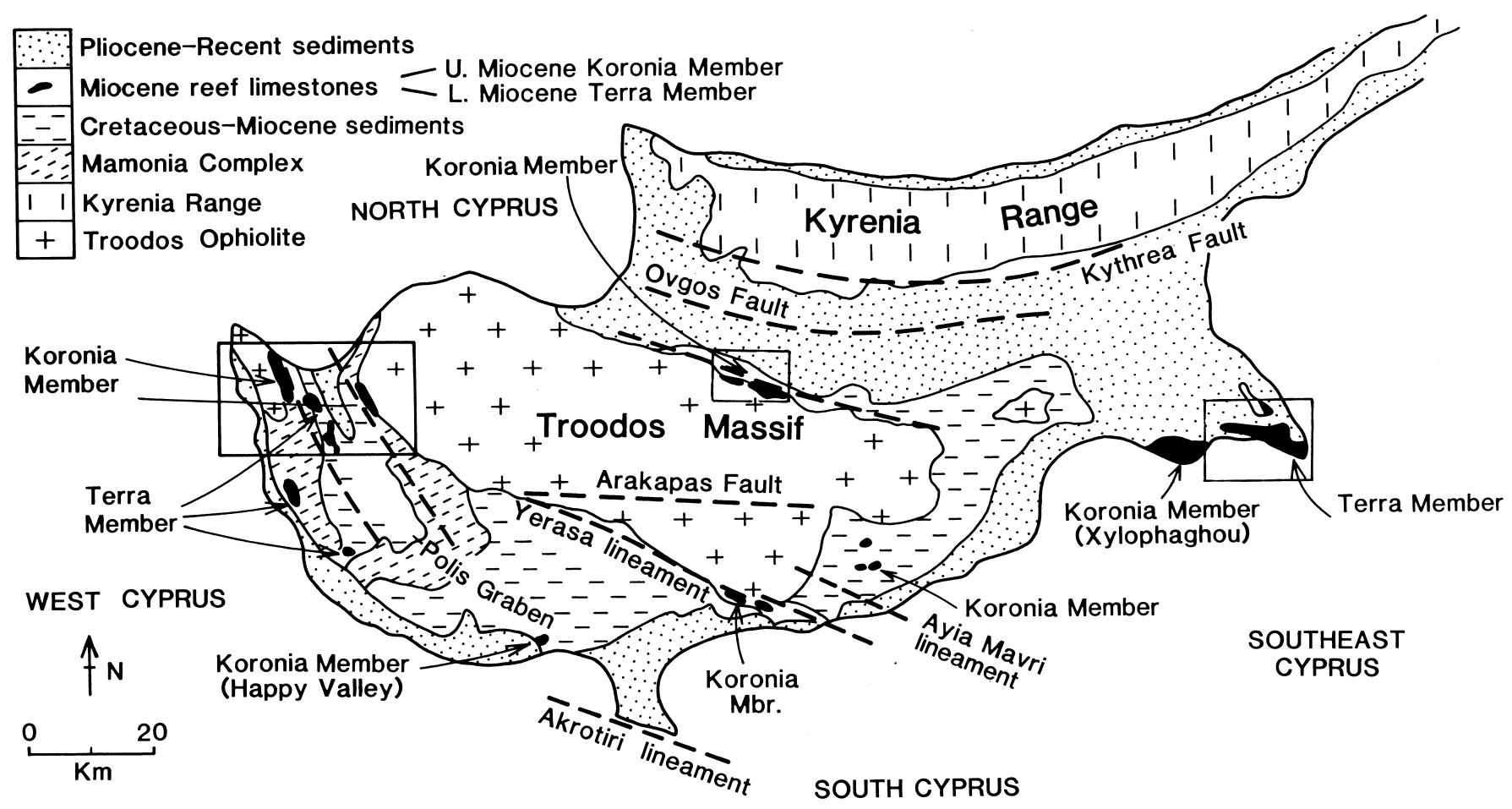

Figure 9. Simplified geological map of Cyprus showing the occurrences of lower and upper Miocene reef limestones. Those most similar to the reef limestones of the Eratosthenes Seamount are found in southeastern Cyprus. From Follows et al. (1996). 


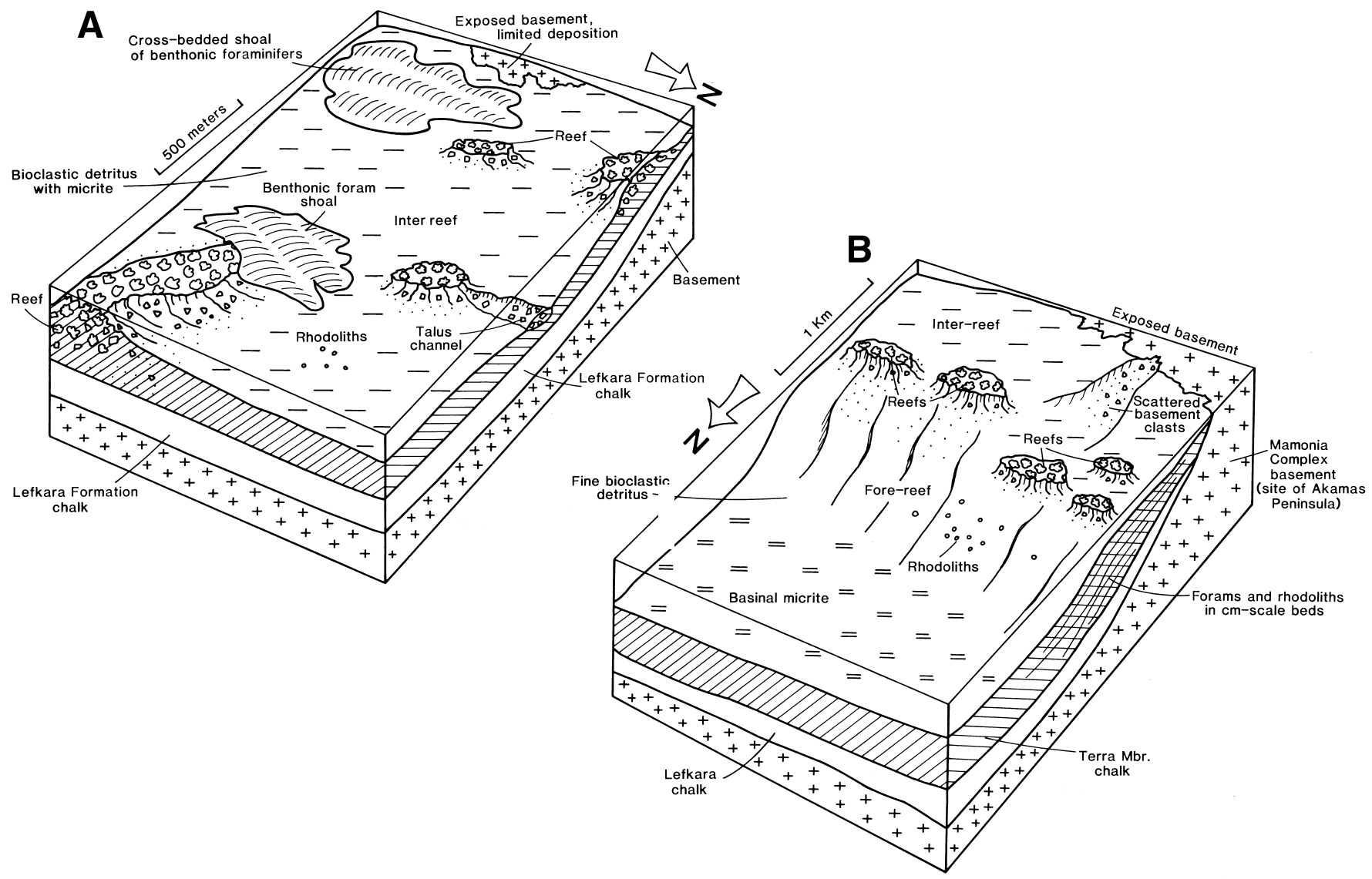

Figure 10. Block diagrams of the lower Miocene Terra Member limestones in Cyprus. A. Southeastern Cyprus. B. Western Cyprus. Those in southeastern Cyprus are similar to the reef limestones of the Eratosthenes Seamount in certain respects. From Follows et al. (1996).

mented coralline and calcareous algal encrusters (i.e., Lithophyllum) and rhodoliths (i.e., Mesophyllum and Lithophyllum). The seafloor topography around the reefs was clearly subdued, on facies evidence.

\section{Upper Miocene Reefs}

The upper Miocene Koronia Member is dominated by reefs that fringed an emergent topography. Diversity is greatly reduced and these reefs are dominated by Porites sp., with Tarbellastrae. The reefs form linear tracts composed of low mounds or sheetlike structures that interfinger with particulate-bedded sediment. Fringing reef tracts were once up to $7 \mathrm{~km}$ long and $2 \mathrm{~km}$ wide, but are now preserved mainly as erosional remnants, as seen along the northern margin of the Troodos ophiolitic massif (Fig. 9). Fore-reef sediments accumulated on slopes and are mixed with terrigenous material that was eroded from local basement units.

\section{Diagenesis of Miocene Reefs in Cyprus}

The diagenesis of the lower Miocene Terra Member began with development of a thin isopachous fringe of acicular, fibrous crystals. This was probably originally high-magnesian calcite and was followed by overgrowth of large, tabular, cement crystals. The early cements are inferred to be of marine origin and were followed by development of micritic internal sediment. Subsequent dissolution of aragonite took place, presumably in response to flushing by meteoric waters. Aragonite is now rarely preserved. Moldic voids were later coated with tabular calcite and, locally, by gypsum that was later pseudomorphed by calcite. The latest cements are coarse calcite spar rich in inclusions. Diagenesis of the Koronia Member is broadly similar. X-ray-diffraction study indicates that the carbonates of both the Terra and Koronia Member are calcite and dolomite. Electron probe data indicate that calcite contains up to $4 \mathrm{~mol} \% \mathrm{Mg}$, similar to the results from the Leg 160 samples analyzed. The Terra and Koronia Members have both experienced patchy dolomitization, especially of horizons rich in benthic foraminifers. Dolomite crystals mainly take the form of euhedral rhombs. Stable isotopic analysis of entirely dolomitized samples revealed values of $\delta^{18} \mathrm{O}$ between $+3.5 \%$ and $+6.1 \%$ and $\delta^{13} \mathrm{C}$ between $0.65 \%$ and $2.2 \%$. Strontium isotopic data suggest that the dolomitizing fluid was $<15.4$ m.y. old.

\section{Southern Turkey}

Lower Miocene (Burdigalian) reef limestones are well developed in southern Turkey within the Manavgat and Köprü basins (Akay et al., 1985; Flecker et al., 1995; Fig. 11). The reefs in the Manavgat basin form linear tracts that fringed a metamorphic basement to the north, the Alanya Massif. The reefs developed on a rugged, sloping paleotopography. The reef limestones are up to $60 \mathrm{~m}$ thick and are dominated by low-diversity types, mainly Tarbellastraea and Porites sp., along with abundant sheetlike red algae and rhodoliths. Intra-reef sediment includes echinoderm spines, fragments of molluscs and brachiopods, together with benthic and rare planktonic foraminifers, and detrital, metamorphic-derived clastic material. The reef limestones are abruptly overlain by a deepening upward succession of pelagic marls of Langhian age, based on dating by the use of calcareous nannofossils (Flecker et al., 1995). Lower Miocene fringing reefs also developed further inland along the margins of the Köprü basin (Flecker, 


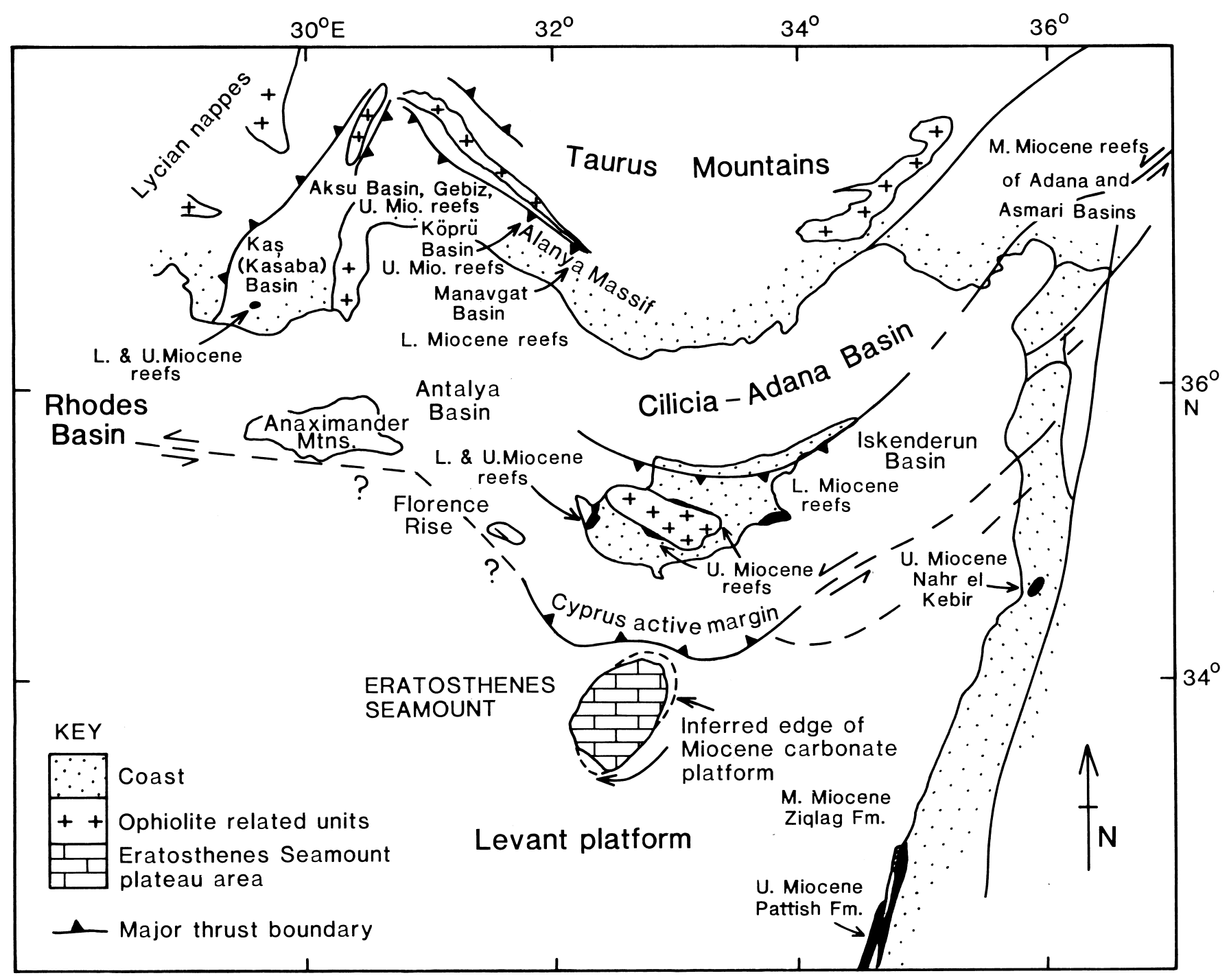

Figure 11. Tectonic map of the easternmost Mediterranean showing the main occurrences of Miocene reefs. See text for explanation.

1995). Small developments of reef limestones of early Miocene age occur further west in the Kaș (or Kasaba) basin where they are restricted to scattered disoriented blocks (the Felenk Dağ Member of the Kemer Formation; Hayward, 1982; Hayward et al., 1996), dated as early Miocene, based upon the benthic foraminiferal assemblage Amphestigina sp., Miogypsina sp., and Nephreolepidina sp. Elsewhere in southern Turkey, lower Miocene reefs are developed in the Adana Basin (Fig. 11).

In general, upper Miocene reefs are less well developed in the Eastern Mediterranean than in the Western Mediterranean. In the Kaş (Kasaba) Basin, the upper Miocene (Tortonian) reefs contain Montastrea, Tarbellastraea, Favites sp., and Porites sp. This unit is underlain by calcareous sandstones of Langhian age. The reef limestone originated as small patch reefs associated with fan-delta conglomerates. Other examples of upper Miocene reef limestones in southwestern Turkey are the Gebiz Limestone in the Aksu basin, and patch reefs in the Köpü basin further northeast (Fig. 11). Most of these reefs record relatively marginal settings with a high input of terrigenous clastic material. A further example is the reefs within the Heraklion basin of northern Crete (Buchbinder, 1996b). These reefs are dominated by Tarbellastraea, Siderastrae, and Porites, but only subordinate favids.

\section{Other Mediterranean Areas}

\section{Levant}

On the Israel coastal plain, the early Miocene was marked by accumulation of calcareous claystones; reef limestones did not develop until the late Burdigalian-Langhian (N8, N9; Ziqlag Formation; Buchbinder, 1975, 1979, 1996a, 1996b; Fig. 11). Lower Miocene reefs also occur further north in the Jeribe and upper Asmari units of Syria and Iraq. In Israel reef limestones again appeared in the Tortonian above Serravallian claystones (Pattish Formation). The Langhian reefs are of a fringing type, overlie upper Eocene-Oligocene marlstones, and are exposed along the western flanks of the Judean Mountains. Platform carbonate, slope, and shelf-edge reef facies are all exposed. The reefs probably formed a discontinuous north-south-trending linear belt. Preserved outcrops of in situ reef limestone are limited, but, where exposed, are of a relatively low-diversity type. The main corals present are massive head-shaped favids, local concentrations of branching stylophorids, with only relatively rare poritids as massive colonies. Lithophyllum and Lithoporella are common calcareous algal genera, and the spaces between the frame builders are occupied by skeletal packstones, with Amphistegina, Operculina, Heterostegina, Borelis, rare Archaias, and Elphidium. These middle 
Miocene reefs formed at the edge of a storm-influenced, open shelf. Upper Miocene reefs are characterized by the Pattish Formation of southern coastal Israel. Preserved outcrops are restricted to small units ( $<5 \mathrm{~m}$ thick), but thicker reefs were probably originally present in reef edge and upper slope areas. Reefs up to $90 \mathrm{~m}$ thick are known from boreholes (Buchbinder, 1996a). Dolomitized Porites colonies dominate, locally associated with Mesophyllum.

\section{Central Mediterranean}

Within the central Mediterranean region lower Miocene reefs are restricted, but include small patch reefs of Aquitanian age in southeastern Sicily. The Middle Miocene was a time of reef decolonization (Pedley, 1979. 1996a). Reefs, of low-diversity type, are more extensively developed in the Tortonian. In many areas (e.g., northern Sicily) reefs are developed in siliciclastic settings. Coral-calcareous algal patch reefs, free of extensive clastic sediments, are widespread in southeastern Sicily, where large carbonate linear ramps developed, with scattered patch reefs in the crestal areas (e.g., Tortonian ramp of southeastern Sicily; Pedley, 1996b). These reefs are mostly of fringing type and are cut by large channels. For current-facing (i.e., windward) ramps, the interior was a partly restricted lagoon where thinlybedded lime mudstones were deposited, whereas in the case of leeward ramps, sedimentation was minimal.

The upper Miocene reefs of the Pelagian Block (e.g., Lampedusa Formation) were isolated from clastic input by rift faults (i.e., Malta graben and Malta escarpment) and thus make an interesting comparison with the Eratosthenes Seamount that also developed as an isolated high surrounded by deep water.

Miocene reefs were also widely developed in the Western Mediterranean. Aquitanian reefs are well developed on Mallorca (Bosence and Pedley, 1982). These reefs are free of terrigenous sediment, locally reach up to $16 \mathrm{~m}$ thick, and extend a few tens of meters laterally. Porites sp. dominates, but other corals are present as massive and encrusting morphologies, together with red microbial boundstones that are located within a matrix of lime mudstones and packstones that contain intraclasts, coral fragments, serpulids, bryozoans, scallops and oysters.

Much work has been published on late Miocene reef development in the Western Mediterranean in relation to the onset of the Messinian salinity crisis (e.g., Esteban, 1996). The majority of these reefs are of fringing type and are often associated with copious terrigenous sediment input, unlike those of the Eratosthenes Seamount.

\section{Comparison with Modern Reefs}

Miocene reefs are distinctive compared with modern and more ancient counterparts in many ways (Esteban, 1996). However, it is worth comparing the Eratosthenes reefs with modern Indo-Pacific examples. Modern atolls are typically constructed on subsiding volcanic edifices (Darwin, 1842; MacNeil, 1954; Grigg, 1982; Scoffin and Dixon, 1983). Peripheral reefs build up as tectonic subsidence continues, whereas lagoonal sediments develop internally (McKee et al., 1959). Sea-level change plays an important role, as documented for Pleistocene reefs (e.g., Barbados; Scoffin, 1987).

\section{DISCUSSION}

Comparison with the Miocene and recent settings show that the Eratosthenes shallow-water limestones resemble the lower Miocene small, localized patch reefs of southeastern Cyprus, that were isolated from terrigenous input (Fig. 11). Similarities with the southern and western Cyprus lower Miocene reefs include the following: (1) the presence of an underlying, eroded pelagic carbonate succession (although the age differs); (2) the accumulation on a low-relief relative- ly tectonically-stable shelf area or platform; (3) the coarse reworked coral-algal sediment at Site 965 resembles the proximal off-reef sediments of southeastern Cyprus; (4) the diagenetic histories are similar, including development of inferred early high-magnesium calcite cement, extensive meteoric water diagenesis and patchy dolomitization; (5) Chert is present in both the Cyprus and Eratosthenes reefs.

There are, however, some differences between the Eratosthenes and southeastern Cyprus reefs: (1) aragonite is quite abundant in the Eratosthenes limestones, but not in Cyprus; (2) gypsum was not observed to precipitate during later diagenesis on the Eratosthenes Seamount (but was inferred to be present on the flank, at Site 967) in contrast to southeastern Cyprus, where the reef limestones were overlain by pelagic carbonate and then influenced by evaporitic conditions during the Messinian; (3) on land, the limestones were exposed to late-stage (i.e., Pleistocene) meteoric water flushing, whereas the Eratosthenes limestone remained submerged; (4) the coral assemblage of the Eratosthenes reefs is less diverse than that of the lower Miocene reefs of Cyprus, although this could be an artifact of limited recovery and poor preservation; and (5) the comparison is based on facies similarities, rather than proven age equivalence, as at least part of the succession at Site 965 is inferred to be late Miocene on the basis of preliminary strontium isotopic dating.

The Eratosthenes reefs are also similar to the local patch reefs of early Miocene age in southeastern Sicily and the Aquitanian patch reefs of Mallorca, Western Mediterranean. However, the Eratosthenes reefs are perhaps most similar of all to the upper Miocene reefs of the Lampedusa shelf, which was isolated from terrigenous input by deep basins, as was Eratosthenes. The Eratosthenes reefs are specifically similar to the Tortonian patch reefs there that developed on an underlying platform of Cretaceous limestone in a relatively stable tectonic setting. Patch reefs and rhodolith packstones pass down slopes into a ramp (i.e., stable ramp of Pedley 1966b) that appears to be present on Eratosthenes based on seismic evidence (Limonov et al., 1994), but was not drilled.

Comparison with the modern Indo-Pacific reefs suggests that the Eratosthenes reefs might have formed an atoll-like structure (Fig. 11). Eratosthenes can be compared with an atoll-like structure as reefs were developed on both the northern (Site 965; Fig. 12) and southwestern margins (dredged coral) of the Eratosthenes carbonate platform, whereas more lagoonal sediment accumulated internally (Site 966). Seismic evidence shows that the former edge of the carbonate platform is still preserved around the western and southern margins of the Eratosthenes Seamount, whereas the northern and northeastern margins have been disrupted by faulting in Pliocene and Pleistocene time (Limonov et al., 1994; Robertson et al., 1995). It is, therefore, possible that the reef was roughly circular, as in atolls. In principal, it is possible that atoll-like structures could develop on a subsiding limestone rather than volcanic basement, but there is insufficient evidence of three dimensional reef structure on Eratosthenes to evaluate the hypothesis of an atoll-like structure (Fig. 13).

\section{Regional Depositional Controls}

The more important controls of Miocene reef development in the Mediterranean were relative sea-level change, climatic change, and tectonic effects. Esteban (1996) emphasized that Miocene Mediterranean reefs appear to be broadly synchronous being "concentrated in the Aquitanian, Langhian (and latest Burdigalian?) and late Tortonian-Messinian intervals." This occurrence "reflects a relationship with second order eustatic sea-level highstands of Haq et al. (1987)." Esteban (1996) also noted that the time of collision of the African and Eurasian plates around the Aquitanian-Burdigalian boundary (20-21 Ma) was marked by intensification of Antarctic glaciation and sealevel fall, and that global cooling took place through the Aquitanian into the early Burdigalian, followed by warming in the late Burdigalian and Langhian. Based on these apparent controls, the occurrence 


\section{Site 965}

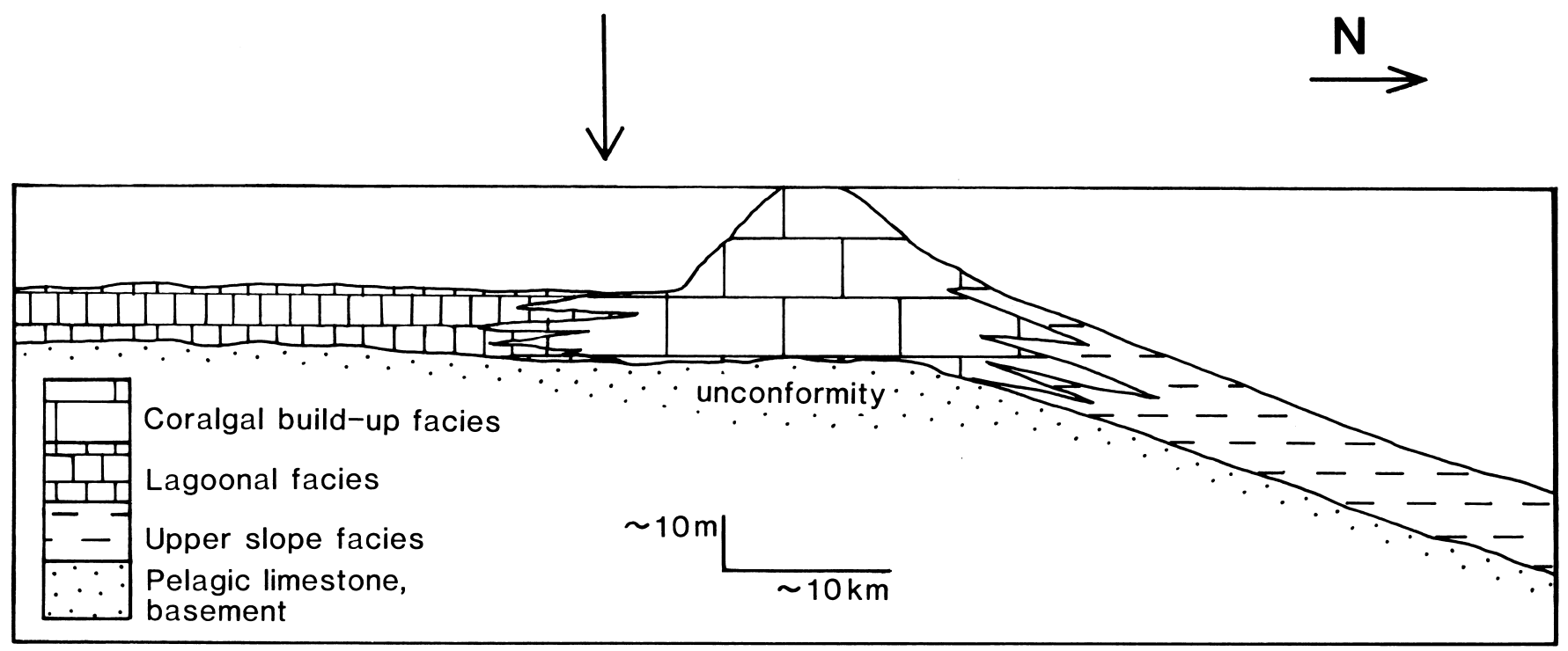

Figure 12. Sketch cross section illustrating the inferred facies relationships at Site 965 during the late Miocene.

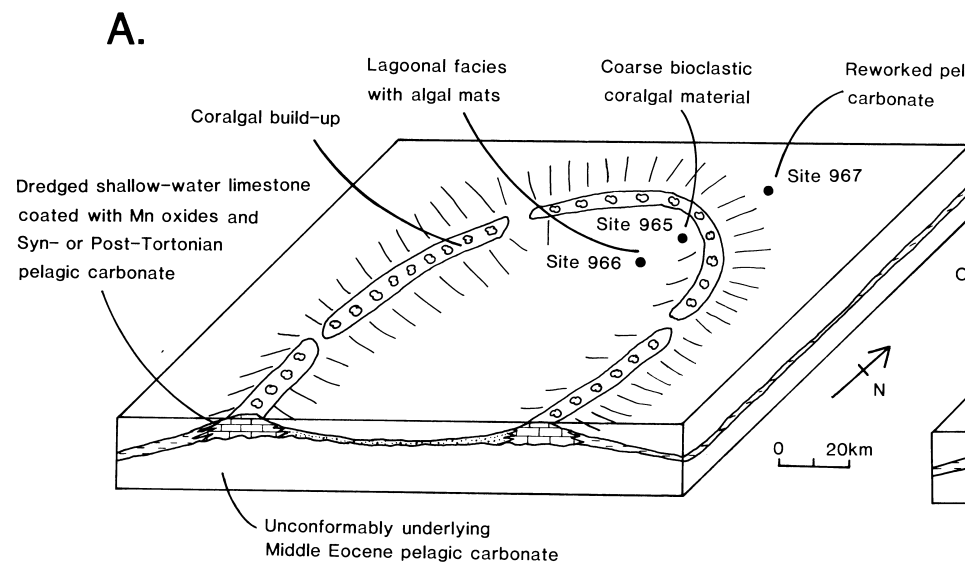

Figure 13. Alternative depositional model for the Eratosthenes Seamount. A. As an atoll-like structure. B. As small patch reefs, variable in space and time. The margins of the shallow-water depositional zone correspond with the present edge of the plateau area, except around the northern and eastern margins that were disrupted by later faulting. See text for explanation.

of lower Miocene (Aquitanian-Burdigalian) reefs in Cyprus and southern Turkey appears to be anomalous. However, if the climatic control was indeed dominant, these reefs could well have been more restricted in time (perhaps to the later Burdigalian) than that suggested by the relatively coarse biostratigraphical age dating currently available. Buchbinder (1996a) further questioned whether the reefs of Cyprus and Southern Turkey could be the same age as the Langhian ones in Israel. However, similar ages are very unlikely as both the Cyprus and Antalya (i.e., Manavgat basin) reefs are overlain by deeper water Langhian marls, in contrast to overlying Serravallian claystones in Israel. A relative sea-level rise in the Langhian could have had the effect of promoting reef development in Israel, whereas in Cyprus the small, patch reefs were drowned, and in southern Turkey (Manavgat and Adana basins), tectonic subsidence played an important role. Any detailed correlation with global eustatic curves is highly questionable in areas such as the Eastern Mediterranean where lo- cal tectonics exerted a major control on relative sea-level change (Robertson et al., 1991). Indeed, at both Eratosthenes and Cyprus, reef development was preceded by tectonic uplift that was possibly related to regional compression (see Robertson, Chap. 51, this volume).

\section{CONCLUSIONS}

Shallow-water, calcareous algae and hermatypic corals flourished on a low-energy reef setting on the Eratosthenes Seamount during Miocene time. The intervals cored mainly record not the reef itself, but, instead, bioclastic material that was reworked by currents into a neighboring, lower energy setting that was dominated by lime mud. At Site 966, the setting was a carbonate shelf on which benthic foraminifers flourished, subject to marine influence that allowed accumulation of planktonic foraminifers. At Site 965, the bioclastic material, 
including coral and calcareous algae, is coarser and the upper part of the interval cored shows evidence of reworking by currents and an open-marine influence. The overall setting at both sites was a subsiding carbonate platform, free of input of terrigenous material other than minor quartz silt, which was probably blown by wind from North Africa.

The Eratosthenes reefs show some similarities with the lower Miocene patch reefs of southern Cyprus, although the diversity of coral types is apparently less. The Eratosthenes reefs are most similar to the upper Miocene reefs of the Lampedusa shelf, central Mediterranean, that developed on a relatively stable limestone platform, located in an open-marine setting isolated from terrigenous input. In one interpretation the Eratosthenes reefs are seen as scattered small patch reefs. In this setting the patch reefs were variable in space and time. In general, Site 965 was located closer to reefs than Site 966 that is more lagoonal. However, coarse reef talus is also present in part of the succession at Site 966 possibly because a small reef migrated close to this site during part of Miocene time. Alternatively, the Eratosthenes reefs may have formed a more atoll-like structure.

The carbonates at both sites show a similar diagenetic history. Aragonite is more common than within the Miocene reef-related limestones of Cyprus, probably because they were not exposed to Pliocene-Pleistocene exposure and meteoric water diagenesis. Boring, formation of micritic envelopes, and early compactive fracturing of shells were followed by precipitation of an isopachous, fibrous fringe cement within the primary voids (e.g., intergranular and intraskeletal). This cement is, however, only rarely preserved, perhaps because of later dissolution. Subsequently, during the Messinian desiccation crisis the platform carbonates were subaerially exposed and, flushed by meteoric water that gave rise to widespread moldic porosity and precipitation of low-magnesium calcite. Aragonitic material (e.g., coral and bivalve shells) underwent extensive neomorphism. Subsequent vadose or early burial calcite spar cement was, however, minimal, probably reflecting an arid climate with restricted fluid flow within the vadose zone. Isopachous calcite spar cement ranges from stubby isopachous to scalenohedral crystals and was followed by coarse blocky and rhombic spar. The micritic matrix underwent variable degrees of recrystallization to calcite spar, which is most advanced in the lower part of the cored interval at Site 966 and may correlate with evidence of pressure dissolution and minor faulting. Dolomite formed in the lower part of the successions at Site 965 and patchily throughout Site 966, possibly in response of mixing of waters of different salinity, related to the Messinian salinity crisis.

\section{ACKNOWLEDGMENTS}

I thank Dr. Brian Rosen (British Museum, Natural History) for examining the coral fragments. Geoff Angel assisted with X-ray diffraction analysis, Alan Collins with electron microprobe analysis, Diana Baty with drafting, and Yvonne Cooper with photography. The manuscript benefited from comments by E. Follows, M. Tucker, and B. D'Argenio.

\section{REFERENCES}

Aissaoui, D.M., 1988. Magnesian calcite cements and their diagenesis: dissolution and dolomitization, Mururoa Atoll. Sedimentology, 35:821-841.

Akay, E., Uysal, S., Poisson, A., Cravette, J., and Müller, C., 1985. Stratigraphy of the Antalya Neogene Basin, Bull. Geol. Soc. Turkey, 28:105-119.

Bosence, D.W.J., and Pedley, H.M., 1982. Sedimentology and palaeoceanography of a Miocene coralline microbial biostrome from the Maltese islands. Palaeogeogr., Palaeoclimatol., Palaeoecol., 28:9-42.

Buchbinder, B., 1975. Lithogenesis of Miocene reef limestones in Israel with particular reference to the significance of red algae. Geol. Surv. Isr. Rept., $\mathrm{D} / 3 / 75$.

1979. Facies and environments of Miocene reef limestones in Israel. J. Sediment. Petrol., 49:1323-1344. 1996a. Middle and Upper Miocene reefs and carbonate platforms in Israel. In Franseen, E.K., Esteban, M., Ward, W.C., and Rouchy, J.-M. (Eds.), Models for Carbonate Stratigraphy from Miocene Reef Complexes of Mediterranean Regions. Concepts Sedimentol. Paleontol., 5:333-346.

1996b. Miocene carbonates of the Eastern Mediterranean, the Red Sea and the Mesopotamian basin: geodynamic and eustatitic controls. In Franseen, E.K., Esteban, M., Ward, W.C., and Rouchy, J.-M. (Eds.), Models for Carbonate Stratigraphy from Miocene Reef Complexes of Mediterranean Regions. Concepts Sedimentol. Paleontol., 5:89-96.

Darwin, C., 1842. The Structure and Distribution of Coral Reefs: London (Smith, Elder).

Emeis, K.-C., Robertson, A.H.F., Richter, C., et al., 1996. Proc. ODP, Init. Repts., 160: College Station, TX (Ocean Drilling Program).

Esteban, M., 1996. An overview of Miocene reefs from Mediterranean areas: general trends and facies. In Franseen, E.K., Esteban, M., Ward, W.C., and Rouchy, J.-M. (Eds.), Models for Carbonate Stratigraphy from Miocene Reef Complexes of Mediterranean Regions. Concepts Sedimentol. Paleontol., 5:3-54.

Evamy, B.D., and Shearman, D.J., 1965. The development of overgrowths from echinoderm fragments. Sedimentology, 5:211-233.

Flecker, R.M., 1995. Miocene basin evolution of the Isparta angle, Southern Turkey [Ph.D. thesis]. Univ. of Edinburgh.

Flecker, R.M., Robertson, A.H.F., Poisson, A., and Muller, C., 1995. Facies and tectonic significance of two contrasting Miocene basins in south coastal Turkey. Terra Nova, 7:221-232.

Follows, E.J., 1990. Sedimentology and tectonic setting of Miocene reef and related sediments in Cyprus [Ph.D. thesis]. Univ. Edinburgh.

, 1992. Patterns of reef sedimentation and diagenesis in the Miocene of Cyprus. Sediment. Geol., 79:225-253.

Follows, E.J., and Robertson, A.H.F., 1990. Sedimentology and structural setting of Miocene reefal limestones in Cyprus. In Malpas, J., Moores, E.M., Panayiotou, A., and Xenophontos, C. (Eds.), Ophiolites: Oceanic Crustal Analogues: Nicosia, Cyprus (Geol. Surv. Dep., Minist. Agric. Nat. Resour.), 207-216.

Follows, E.J., Robertson, A.H.F., and Scoffin, T.P., 1996. Tectonic controls of Miocene reefs and related carbonate facies in Cyprus. In Franseen, E.K., Esteban, M., Ward, W.C., and Rouchy, J.-M. (Eds.), Models for Carbonate Stratigraphy from Miocene Reef Complexes of Mediterranean Regions. Concepts Sedimentol. Paleontol., 5: 295-316.

Franseen, E.K., Esteban, M., Ward, W.C., and Rouchy, J.-M. (Ed.), 1996. Models for carbonate stratigraphy from Miocene reef complexes of Mediterranean regions. In Franseen, E.K., Esteban, M., Ward, W.C., and Rouchy, J.-M. (Eds.), Models for Carbonate Stratigraphy from Miocene Reef Complexes of Mediterranean Regions. Concepts Sedimentol. Paleontol., 5 .

Grigg, R.W., 1982. Darwin Point: a threshold for atoll formation. Coral Reefs, 1:29-34.

Haq, B.U., Hardenbol, J., and Vail, P.R., 1987. Chronology of fluctuating sea levels since the Triassic. Science, 235:1156-1167.

Hayward, A.B., 1982. Tertiary ophiolite-related sedimentation in S.W. Turkey [Ph.D. thesis]. Univ. of Edinburgh

Hayward, A B., Robertson, A.H.F., and Scoffin, T.P., 1996. Miocene patch reefs from a Mediterranean marginal terrigenous setting in S.W. Turkey. In Franseen, E.K., Esteban, M., Ward, W.C., and Rouchy, J.-M. (Eds.), Models for Carbonate Stratigraphy from Miocene Reef Complexes of Mediterranean Regions. Concepts Sedimentol. Paleontol., 5:317-332.

Hird, K., and Tucker, M.E., 1988. Contrasting diagenesis of two Carboniferous oolites from South Wales: a tale of climatic influence. Sedimentology, 35:587-602.

James, N.P., Conglio, M., Aissaoui, D.M., and Purser, B.H., 1988. Facies and geologic history of an exposed Miocene rift-margin carbonate platform: Gulf of Suez, Egypt. AAPG Bull., 72:55-572.

Krasheninnikov, V.A., Udintsev, G.B., Mouraviov, V., and Hall, J.K., 1995. Geological structure of the Eratosthenes Seamount. In Krasheninnikov, V.A., and Hall, J.K. (Eds.), Geological Structure of the Northeastern Mediterranean (Cruise 5 of the Research Vessel Akademik Nokolaj Strakhov): Jerusalem (Historical Productions-Hall Ltd.), 113-130.

Land, L.S., 1970. Phreatic vs. vadose meteoric diagenesis of limestones: evidence from a fossil water table. Sedimentology, 14:175-185.

Limonov, A.F., Woodside, J.M., and Ivanov, M.K. (Eds.), 1994. Mud Volcanism in the Mediterranean and Black Seas and Shallow Structure of the Eratosthenes Seamount. Initial Results of the Geological and Geophysical Investigations during the Third "Training-through-Research" Cruise 
of the $R / V$ Gelendzhik (June-July 1993). UNESCO Rep. Mar. Sci., G4:83-100.

MacNeil, F.S., 1954. The shape of atolls: an inheritance from subaerial erosion forms. Am. J. Sci., 2522:402-427.

McKee, E.D., Chronie, J., and Leopold, E.B., 1959. Sedimentary belts in the lagoon of Kapingamarangi Atoll. AAPG Bull., 43:1206-1212.

Pedley, H.M., 1979. Miocene bioherms and associated structures in the coralline limestones of the Maltese Islands: their lithification and palaeoenvironment. Sedimentology, 26:571-591.

, 1996a. Miocene reef distributions and their associations in the Central Mediterranean: an overview. In Franseen, E.K., Esteban, M., Ward, W.C., and Rouchy, J.-M. (Eds.), Models for Carbonate Stratigraphy from Miocene Reef Complexes of Mediterranean Regions. Concepts Sedimentol. Paleontol., 5:73-88.

1996b. Miocene reef facies of the Pelagian region (Central Mediterranean). In Franseen, E.K., Esteban, M., Ward, W.C., and Rouchy, J.M. (Eds.), Models for Carbonate Stratigraphy from Miocene Reef Complexes of Mediterranean Regions. Concepts Sedimentol. Paleontol., 5:247-260.

Purser, B.H., 1969. Syn-sedimentary marine lithification of Middle Jurassic limestones in the Paris basin. Sedimentology, 12:205-230.

Robertson, A.H.F., Eaton, S., Follows, E.J., and McCallum, J.E., 1991. The role of local tectonics versus global sea-level change in the Neogene evolution of the Cyprus active margin. In Macdonald, D.I.M. (Ed.), Sedimentation, Tectonics and Eustacy Sea-level Changes at Active Margins. Spec. Publ. Int. Assoc. Sedimentol., 12:331-369.

Robertson, A.H.F., Kidd, R.B., Ivanov, M.K., Limonov, A.F., Woodside, J.M., Galindo-Zaldivar, J., and Nieto, L., 1995. Eratosthenes Seamount, easternmost Mediterranean: evidence of active collapse and thrusting beneath Cyprus. Terra Nova, 7:254-265.

Robertson, A.H.F., and Shipboard Scientific Party, 1996. Role of the Eratosthenes Seamount in collisional processes in the Eastern Mediterranean. In Emeis, K.-C., Robertson, A.H.F., Richter, C., et al., Proc. ODP, Init. Repts., 160: College Station, TX (Ocean Drilling Program), 513520.

Scoffin, T.P., 1987. An Introduction to Carbonate Sediments and Rocks: London (Blackie).

Scoffin, T.P., and Dixon, J.E., 1983. The distribution and structure of coral reefs: one hundred years since Darwin. Biol.J., 20:11-38.

Tucker, M.E., and Bathurst, R.G.C., 1990a. Diagenesis in the burial environment. In Tucker, M.E., and Bathurst, R.G.C. (Eds.), Reprint Series Volume 1. Internat. Assoc. Sedimentol., 225-228.

1990b. Marine diagenesis: modern and ancient. In Tucker, M.E., and Bathurst, R.G.C. (Eds.), Reprint Series Volume 1. Internat. Assoc. Sedimentol., 10-11.

, 1990c. Meteoric diagenesis: modern and ancient. In Tucker, M.E., and Bathurst, R.G.C. (Eds.), Reprint Series Volume 1. Internat. Assoc. Sedimentol., 181-184.

Date of initial receipt: 24 January 1997

Date of acceptance: 24 June 1997

Ms 160SR-036 